\title{
鋳造冠の支台歯形態に関する実験的研究
}

一一軸面傾斜度ならびに歯頸部辺縁形態について——

橋 本収

\section{Effect of Types of Preparated Abutment Teeth on Full Cast Metal Crowns}

\author{
Osamu Hashimoto
}

\begin{abstract}
緒言
鋳造冠は, 歯科臨床において占める割合が最も高く, 単独冠はもとより架工義歯の支台装置として用いられて いる.したがつて, 鋳造冠の製作に関して多くの研究が なされ，かつ材料，技術などの進歩とともに，鋳造冠の 寸法精度はかなり改善されてきたが, 鋳造冠の歯頸部に おけるセメント層や接触点などを含めて，まだ未解決の 問題点が, 残されている.

これらの問題を解決するためには，鋳造冠の製作過程 における各操作すなわち支台歯形成から始をり，印象採 得, 模型製作, 口ウ型採得, 鋳造, 研磨, 装着に至るま での因子が, 鋳造冠の外形寸法, 適合度, セメント合着 による浮き上がり, 歯頸部辺縁のセメント層, および保 持力などの各種条件に及ぼす影響を同時にとらえ，臨床 的な立場から総合的な検討を加える必要があると考えら れる.しかし, 従来の研究は, たとえば装着におけるセ メントの破研抗力が鋳造冠の保持力に及ぼす影響 $\left.{ }^{1}, 2\right)$, あるいは埋没条件が 鋳造冠の適合度におよぼす影響3 などのごとく，鋳造冠製作過程の一因子と鋳造冠の一条 件について，あるいは数因子と一条件についての基礎的 な報告が多い。

鋳造冠の各種条件に影響を及ぼす製作過程の因子のな かでも，とくに支台歯形成はその出発点であり，印象採 得以後の操作に影響を及ぼすのみならず, 鋳造冠の各種

* Ist Department of Prosthetic Dentistry, Osaka University Dental School. (Director: Prof. Takaji Simoosa)

* 大阪大学歯学部歯科補緅学第 1 教室（指導: 下総高次教 授)

昭和 47 年 3 月 28 日
\end{abstract}

条件すべてに影響を与えると考えられ，臨床上重要な操 作である，そして支台歯形成のなかでも，支台歯形態は とくに重要である.しかしながら,支台歯形態に関して, 軸面傾斜度および歯頸部辺縁形態が鋳造冠に及ぼす影響 についての報告 ${ }^{4 \sim 9)}$ はあるが, 軸面傾斜度と歯頸部辺縁 形態との相互関係が鋳造冠の各種条件に及ぼす影響につ いては，系統的に検討した研究報告がみられない．

そこで本研究は，基䃈的研究の一環として，鋳造冠の 支台歯形態にとつて重要な因子である軸面傾斜度ならび に歯頸部辺縁形態をとりあげ, それらが鋳造冠の外形寸 法, 適合度, セメント合着による浮き上がり, 歯頸部辺 縁のセメント層, および保持力にどのような影響を及ぼ すかを知るために, 補緅学的立場から総合的な検討を加 えたものである.

\section{実䀦材料ならびに方法}

\section{実験 I：外形の寸法変化}

外形の寸法変化は, 口ウ型および鋳造冠の外形寸法を 計測し, 両者を比較することによつて変化量を求めた.

a) 金 型

小臼歯の単独冠を想定し, 単純化した図 1) のごとき 形態, 寸法のステンレススチール製外枠金型（図 2) を 使用した. 支台歯は, (図 3 )のごとく, 歯頸部直径, 高さ を一定にして, 軸面傾斜度が $2^{\circ}, 5^{\circ}, 10^{\circ}, 15^{\circ}$ の 4 種類, それらに対する歯頸部辺縁形態をそれぞれ knife edge type, chamfer type, shoulder type の 3 種類とし, 合 計 12 種類のステンレススチール製の支台歯（図 4) を使 用した。

b ) ロウ型採得

軟化圧接法により行なつた. すなわち, 支台歯および 


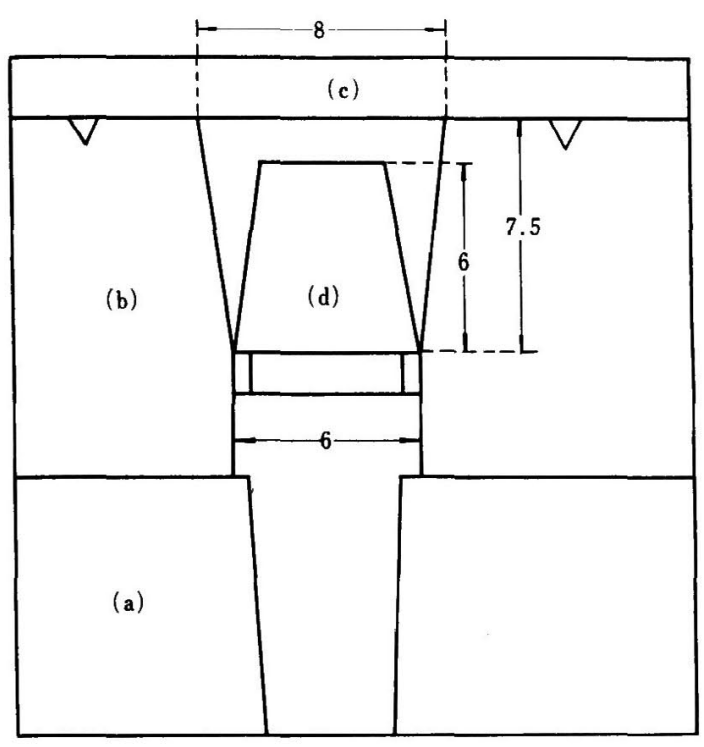

图 1 金型の設計図 (単位: $\mathrm{mm}$ )
(a) 支台歯支持部
(c) 天 蓋
(b) 外 枠
(d) 支台歯

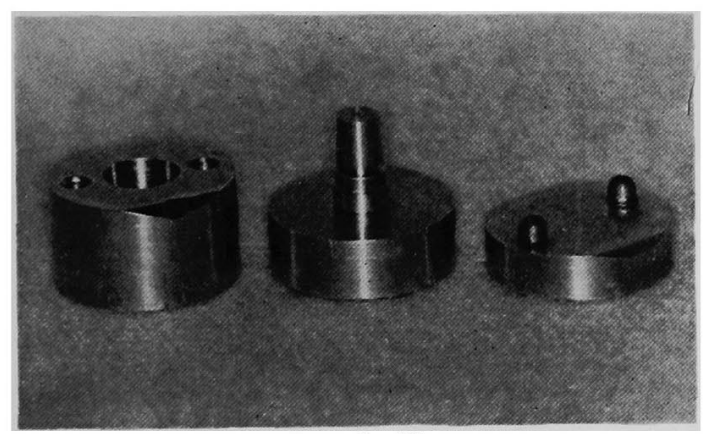

図 2 金 型

左から外枠, 支台歯および支持部, 天蓋
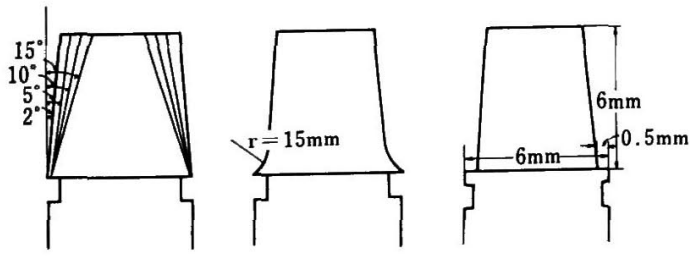

knife edge type

chamfer type

shoulder type

図 3 支台歯の形態および寸法

外枠に分離剤を塗布し， G 社製間接法用インレーワック スと共に約 $44^{\circ} \mathrm{C}$ の oven に入れて軟化し, 約 $5 \mathrm{~kg} の$ 加重を行ない室温をで泠却した，余剩のワックスをカミ ソリにて削除成形し, 天蓋中央部に直径 $1.8 \mathrm{~mm}$ の中

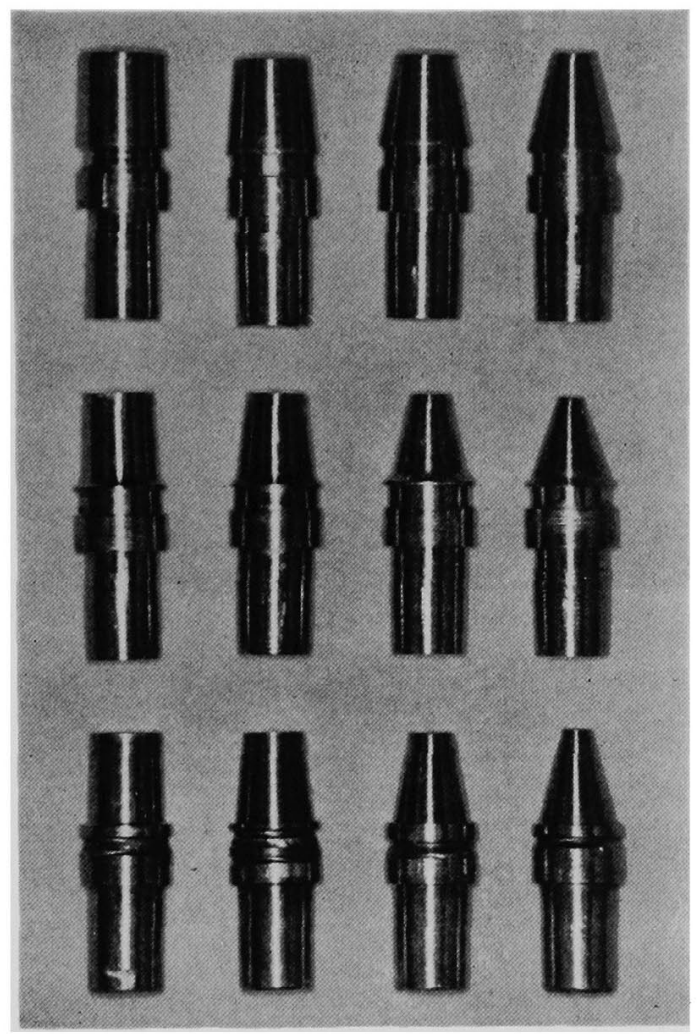

図 4 実験 I ) に使用したステンレス スチール製の支台歯 上段 : knife edge type 中段: chamfer type 下段 : shoulder type それぞれ左から $2^{\circ}, 5^{\circ}, 10^{\circ}, 15^{\circ}$

空スプルー線を植立した，口ウ型と支台歯の位置関係を 印記し，支台歯を Galloni 製 Isopalallero meter (図 5 ）に固定し, 回転させながら, 移動台に固定した針に よつてロウ型の周囲に測定基準線を描記した，なお，測 定基淮線は上縁より $0.7 \mathrm{~mm}$ および $6.3 \mathrm{~mm}$ の 2 力所 に印記した。

c）ロウ型の測定

支台歯を試料載物台に 固定し, Nikon 製万能投影機 6C-T 型にて投影を行ない，精度 $1 / 1,000 \mathrm{~mm}$ の微動载 物台の移動量を読み取り， ロウ型の外形寸法を計測し た. 測定部位は図 6 に示した (a)〜 (g) の7 部位である. 測定は各試料の $120^{\circ}$ 間隔に 3 方向より行なつた.

d) 埋 没

スプルー線の長さが $5 \mathrm{~mm}$ になるように円錐台に植 立し, wax pattern cleaner で清掃を行なつた. 内径 $30 \mathrm{~mm}$, 高さ $36 \mathrm{~mm}$ の埋没リングに, S 社製アスベス 


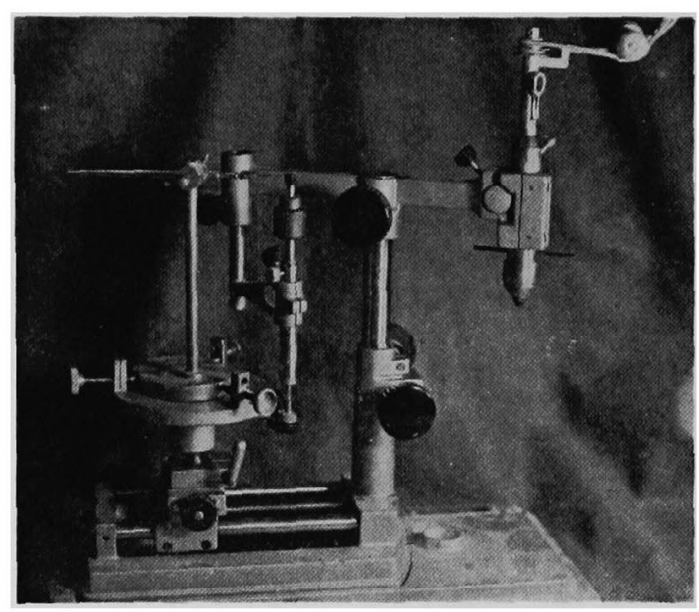

図 5 Isopalallero meter 使用して，ロウ 型に測定基準線を描記しているところ

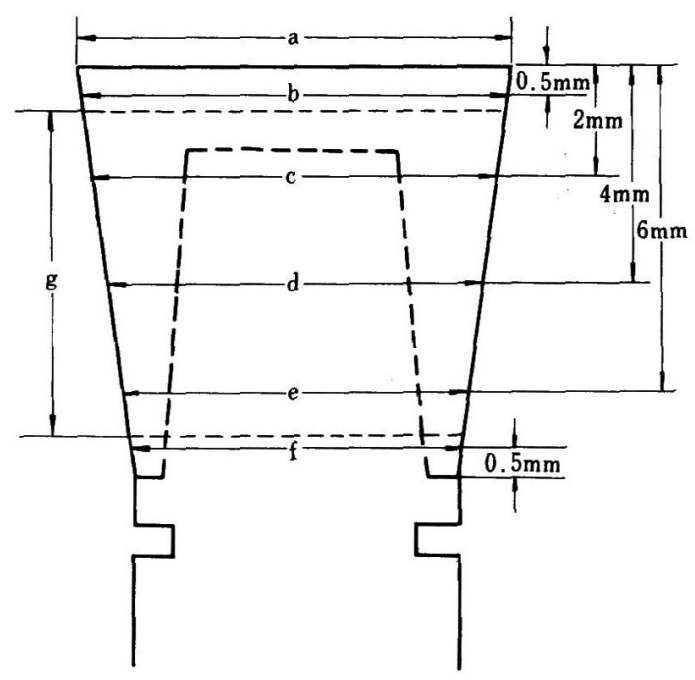

図 6 口ウ型および鋳造冠外形の 測定部位

トリボン 4 枚（合計 $1.6 \mathrm{~mm}$ ）を継ぎ目が 4 方向に分散 するように裏装し，ワセリンを一層塗布した，埋没材 は，松風クリストバライト埋没材 (Batch No. 980) を 混水比0.35にて使用し, Torit 真空攪拌埋没器で $50 \mathrm{sec}$ 攪拌練和後, 真空埋没を行なつた. なお, 口ウ型採得か ら埋没までの操作は室温 $24 \sim 27^{\circ} \mathrm{C}$ で行なつた.

e ）焼却および鋳造

埋没 10〜15 hrs 後, Auto-furnace ( $\mathrm{D}$ 社製) を使用 し, 平均昇温速度 $10.3^{\circ} \mathrm{C} / \mathrm{min}$ で $700^{\circ} \mathrm{C}$ ま 温度上昇 を行ない, $700^{\circ} \mathrm{C} に 30 \mathrm{~min}$ 慗留した.

鋳造には Torit 縦型遠心鋳造機を 2 回巻で使用し,

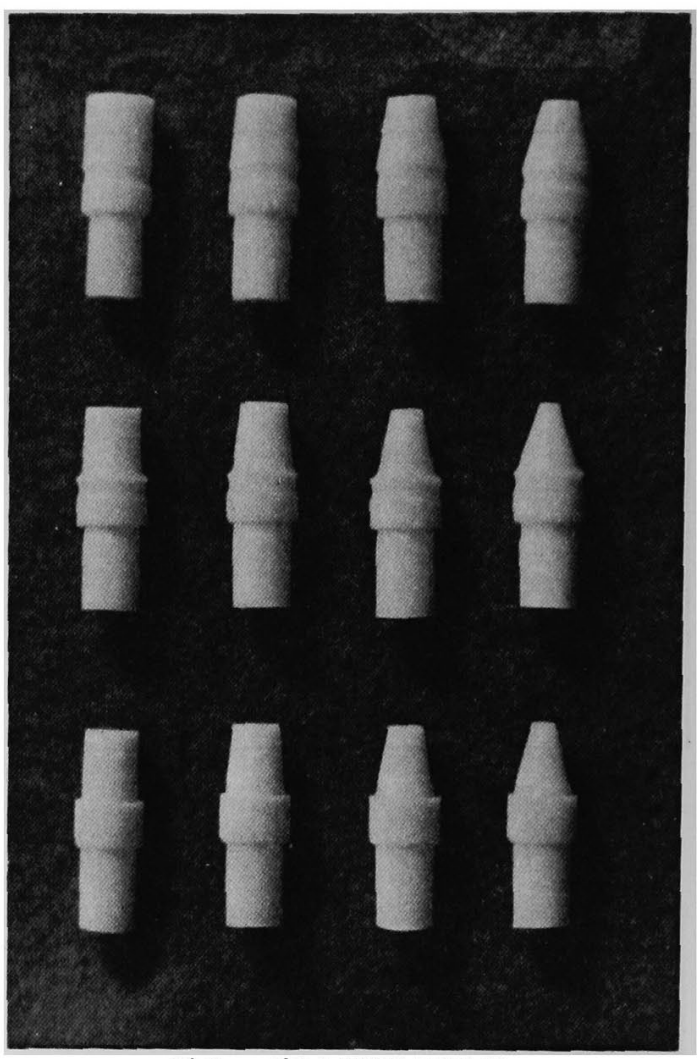

图 7 エポキシ樹脂性の支台歯 上段 : knife edge type 中段 : chamfer type 下段: shoulder type それぞれ左から $2^{\circ}, 5^{\circ}, 10^{\circ}, 15^{\circ}$

金属は金含有量 $10 \%$ 金パラジウム銀合金（G社製）を 各試料に $4 \mathrm{~g}$ 宛使用した. 鋳造後放冷して, 埋没材を除 去し，パラジウム清掃剂 ( $G$ 社製) で処理した.

f ) 鋳造冠の測定

ロウ型の測定と同じ方法で, 測定基準線にしたがい, 鋳造冠の外形寸法を計測した.

なお, 試料は各形態につき 6 個, 合計72個製作した.

実験 II : 適合度

適合度の測定には，実験 I ）と同じ形態，寸法の支台 歯をエポキシ樹脂で製作して使用した（図 7 ).

口ウ型採得は実験 I ) と同じ方法で行ない, 明石硬度 計を使用して， ロウ型および支台歯に測定点を印記し， 付属の微動載物台（精度 $1 / 1,000 \mathrm{~mm}$ ) の移動量を読み 取り，両印記点間の距離を計測した。 以上の操作を試料 の 3 方向より行ない, 実験 I ) と同じ方法で埋没, 鋳造 を行なつた. 
(a)

(b)

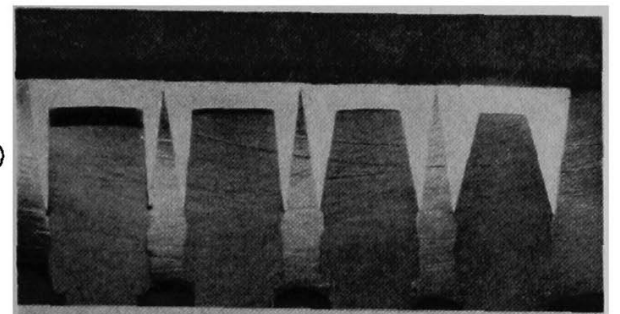

(c)

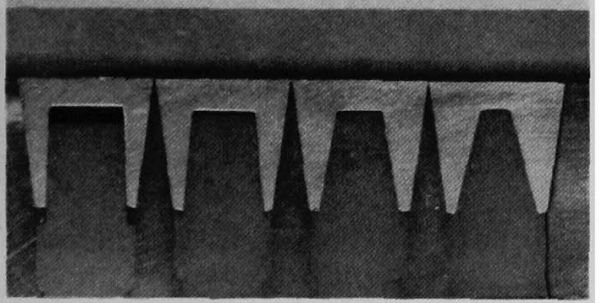

図 8 セメント合着後の中央部切断面
(a) knife edge type
(b) chamfer type
(c) shoulder type
それぞれ左から $2^{\circ}, 5^{\circ}, 10^{\circ}, 15$

鋳造冠完成後支台歯にもどし， $400 \mathrm{~g}, 5 \mathrm{~kg}$ ，および30 $\mathrm{kg}$ の加重を行なつた後, 口ウ型の場合と同じ方法で, 鋳造冠と支台歯の両印記点間の距離を計測した.ロウ型 と支台歯, および鋳造冠と支台歯の距離を比較して, 口 ウ型に対する鋳造冠の浮き上がり量をたは沈下量を求め て, 適合度の判定を行なつた, 加重量の判定には, 日本 光電製咬合力測定器を使用した. なお, 試料は各形態に つき 6 個宛製作した.

\section{実験 III：セメント合着による浮き上がり}

セメント合着による浮き上がり量を測定するため, 実 験 II）で使用した試料を 松風マイクロセメント（Batch No. 30）で合着した. セメントの粉液比は, 指定にした がい, $\mathrm{L} / \mathrm{P}=0.5 \mathrm{cc} / 1.47 \mathrm{~g}$ の標準稠度とし, 練和方法は JIS-T 6602 によつて $90 \mathrm{sec}$ 練和した. セメント合着 時には, セメント練和開始から $10 \mathrm{~min}, 30 \mathrm{~kg}$ の一定加 重を行なつた. セメント硬化後, 余剩のセメントを取り 除き，実験 II）と同じ方法で支台歯と鋳造冠の距離を計

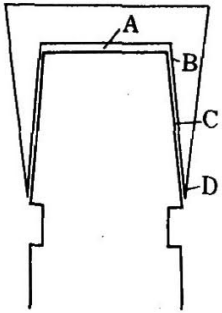

knife edge type

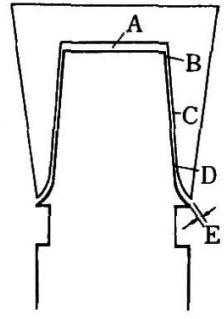

chamfer type

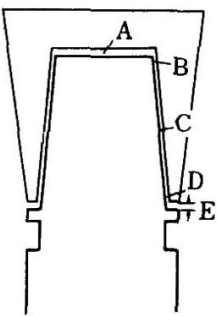

shoulder type
図 9 切断面におうけるセメント層の厚さの測定部位
(A) 天蓋部
(B) 側壁上方部
(C) 側壁中央部
(D) 側壁下方部
(E) 歯顥部辺縁

測し, 実験 II）の計測值と比較して, セメント合着によ る浮き上がり量を求めた.

\section{実験 IV : 切断面のセメント層}

セメント合着した試料のうち, 歯頸部辺縁形態が同じ で軸面傾斜度が異なる 4 種類の試料を, 咬合面部ががラ ス板に接するように一直線にならべ，即持重合レジンで 固定後, エピコート樹脂で包埋した. 硬化後, 切断器10) にて試料の長軸方向に切断し，4 個つ試料つ中央部まで 研磨を行なつた（図 8 ）. この場合，万能投影機を使用 して，透過および反射を同時に行ない，透過像と反射像 が一致することにより, 試料の中央部で切断されている ことを確認した.

切断面のセメント層の測定には万能投影機を使用し， 測定部位は図 9 に示した $(\mathrm{A})$ ～(E) である. 試料は各形態 につき 6 個宛製作した.

\section{実験 V: 保持力}

鋳造冠の保持力を判定するため, 引張り強さを測定し た.

軸面傾斜度の差異による引張り強さを測定するため に, 䱊頸部辺縁形態が knife edge type の場合につい て, 軸面傾斜度が $2^{\circ}, 5^{\circ}, 10^{\circ}, 15^{\circ}$ の 4 種類の支台歯を対 象とした. また, 歯頸部辺縁形態の差異による引張り強 さを測定するために, 軸面傾斜度が $10^{\circ}$ の場合につい $\tau$, 歯頸部辺縁形態が knife edge type, chamfer type, shoulder type の 3 種類の支台歯を対象とした.

支台歯の製作は，ウ蝕のない抜去歯牙を使用して， bur に固定した歯牙を Isopalallero meter (図 5 ) で回 転させながら, 移動台に固定したエアータービンを所定 の角度に保ち(図10), エンジン部を上下方向, タービン 部を前後左右方向に移動させて, 所定の支台䨑形態掞よ ぴ寸法に形成した(図11，12). 


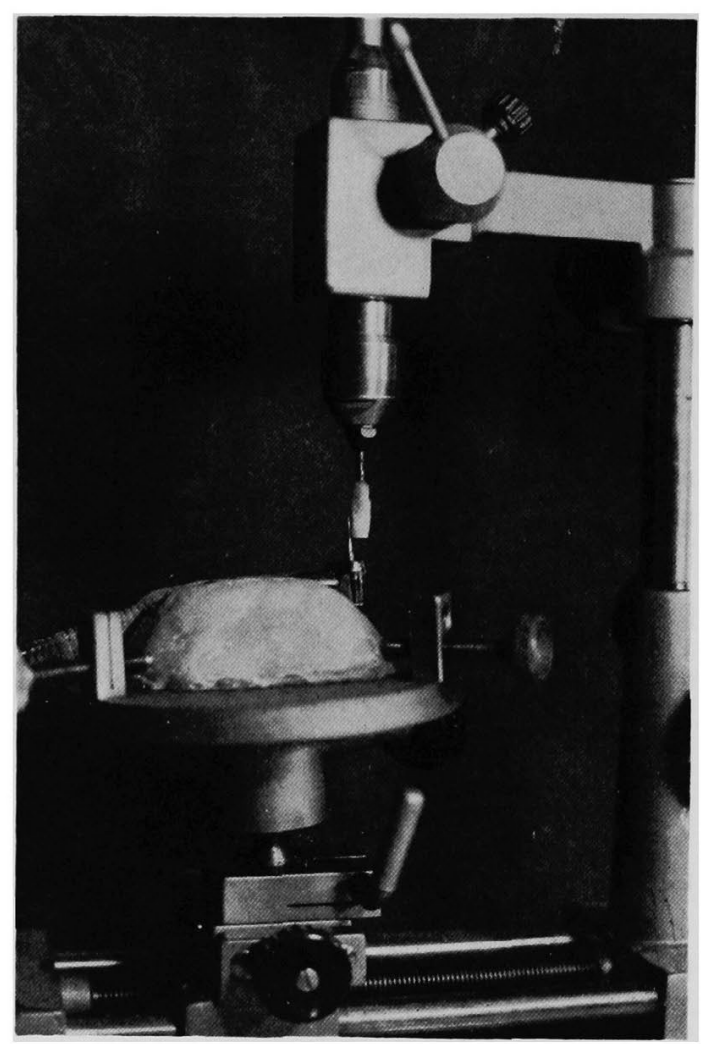

図10拔去歯牙の支台歯形成 (Isopalallero meter)

鋳造冠の製作は実験 I），セメント合着は実験 III）と 同じ方法で行ない，セメント練和開始から $10 \mathrm{~min}$ 後, $37^{\circ} \mathrm{C}$, 湿度 $99 \%$ に保ったミク口 型透視式恒温恒湿器に $24 \mathrm{hrs}$ 試料を保存した.

引張り強さの測定にはアムスラー型材料試験機を使用 し, 支台歯と鋳造冠が離脱するに要した力を求めた. 試

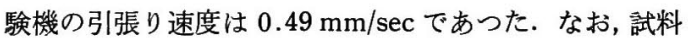
は各支台歯形態につき 6 個ずつ製作した.

付）ピンレッヂの保持力

拔去歯牙の小画を使用して, 通法により咬合面の削 除を行ない, 700 \#の fissure burで長さ $2 \mathrm{~mm}$ のピン ホールを舌側に 1 本, 賽側に 2 本形成した.

軟化圧接法でロウ型採得を行ない, 以後鋳造冠と同じ 方法によって引張り強さを測定した。

\section{実験 結果}

実験 I : 外形の寸法変化

外形の寸法変化は，(a)〜(g)（図6）におけるロウ型

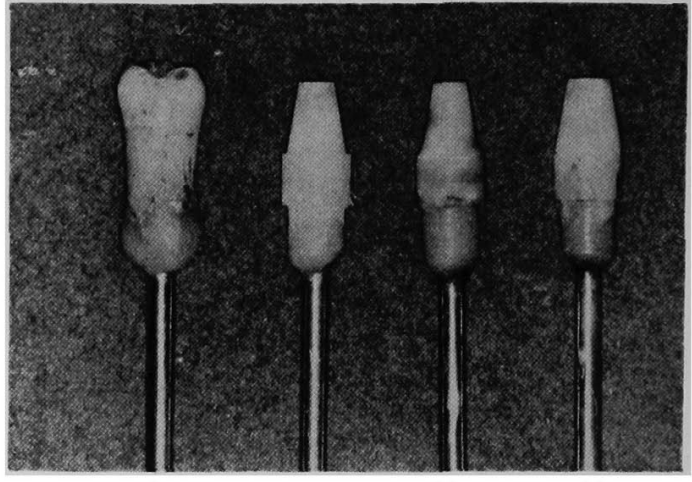

(2)

(3)

(4)

図11 支台歯（抜去歯牙）

(1) 形成前

(2) shoulder type (軸面傾斜度 $10^{\circ}$ )

(8) chamfer type (")

(4) knife edge type ( " ')

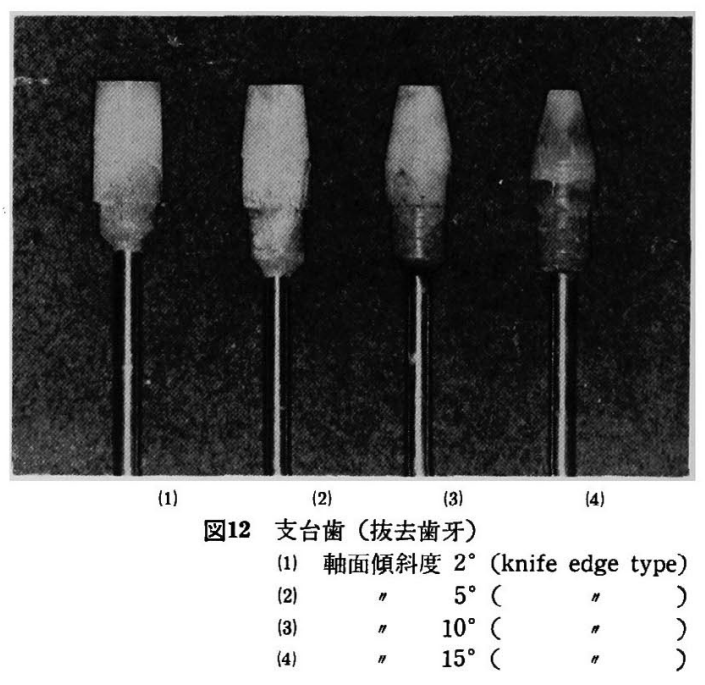

の計測值 $\mathrm{L}_{\mathrm{w}}$, および鋳造冠の計測值 $\mathrm{L}_{\mathrm{c}}$ より，次式で 膨縮率に換算した.

$$
\text { 膨縮率 }=\frac{L_{w}-L_{c}}{L_{w}} \times 100
$$

結果を表 1)，2），3）に示した.

鋳造冠の長軸方向 $(\mathrm{g})$ は, $0.48 \sim 0.69 \%$ の膨張を示し， 軸面傾斜度および歯頸部辺縁形態による変化は認められ なかつた。

鋳造冠の 横軸方向 (a) ( f) の結果をグラフにあらわす と図13，14，15）となる.

各々の辺縁形態についてみてみると, knife edge type の場合には，表1）および図13）に示したように，冠上 縁部 (a) は，0.58 0.65\% の収縮を示し，軸面傾斜度に 
表 1 鉱造冠外形の寸法変化 (knife edge type)

\begin{tabular}{|c|c|c|c|c|c|c|c|}
\hline 部位 & a & b & c & $d$ & $\mathrm{e}$ & f & $\mathrm{g}$ \\
\hline $2^{\circ}$ & $\begin{array}{c}-0.65 \\
(0.10)\end{array}$ & $\begin{array}{c}-0.84 \\
(0.08)\end{array}$ & $\begin{array}{c}-0.80 \\
(0.07)\end{array}$ & $\begin{array}{c}-0.62 \\
(0.08)\end{array}$ & $\begin{array}{c}-0.29 \\
(0.10)\end{array}$ & $\begin{array}{c}+0.02 \\
(0.12)\end{array}$ & $\begin{array}{c}+0.62 \\
(0.08)\end{array}$ \\
\hline $5^{\circ}$ & $\begin{array}{c}-0.61 \\
(0.10)\end{array}$ & $\begin{array}{c}-0.80 \\
(0.09)\end{array}$ & $\begin{array}{c}-0.85 \\
(0.06)\end{array}$ & $\begin{array}{c}-0.67 \\
(0.07)\end{array}$ & $\begin{array}{c}-0.31 \\
(0.09)\end{array}$ & $\begin{array}{c}-0.04 \\
(0.12)\end{array}$ & $\begin{array}{c}+0.60 \\
(0.07)\end{array}$ \\
\hline $10^{\circ}$ & $\begin{array}{c}-0.64 \\
(0.08) \\
\end{array}$ & $\begin{array}{c}-0.82 \\
(0.09)\end{array}$ & $\begin{array}{c}-0.85 \\
(0.08)\end{array}$ & $\begin{array}{c}-0.70 \\
(0.06)\end{array}$ & $\begin{array}{c}-0.48 \\
(0.07)\end{array}$ & $\begin{array}{c}-0.14 \\
(0.08)\end{array}$ & $\begin{array}{c}+0.53 \\
(0.06)\end{array}$ \\
\hline $15^{\circ}$ & $\begin{array}{c}-0.58 \\
(0.08)\end{array}$ & $\begin{array}{r}-0.86 \\
(0.09\end{array}$ & $\begin{array}{c}-0.88 \\
(0.08)\end{array}$ & $\begin{array}{c}-0.81 \\
(0.08)\end{array}$ & $\begin{array}{c}-0.61 \\
(0.07)\end{array}$ & $\begin{array}{c}-0.31 \\
(0.08)\end{array}$ & $\begin{array}{c}+0.64 \\
(0.07)\end{array}$ \\
\hline
\end{tabular}

nit : \%

( ) : s.d.

表 2 鋳造冠外形の寸法変化 (chamfer type)

\begin{tabular}{|c|c|c|c|c|c|c|c|}
\hline 部位 & a & b & c & $\mathrm{d}$ & e & $\mathbf{f}$ & $\mathrm{g}$ \\
\hline $2^{\circ}$ & $\begin{array}{c}-0.54 \\
(0.11)\end{array}$ & $\begin{array}{c}-0.80 \\
(0.10)\end{array}$ & $\begin{array}{c}-0.97 \\
(0.08)\end{array}$ & $\begin{array}{r}-1.02 \\
(0.06)\end{array}$ & $\begin{array}{c}-0.97 \\
(0.08)\end{array}$ & $\begin{array}{c}-0.74 \\
(0.07)\end{array}$ & $\begin{array}{c}+0.69 \\
(0.08)\end{array}$ \\
\hline $5^{\circ}$ & $\begin{array}{r}-0.66 \\
(0.09)\end{array}$ & $\begin{array}{r}-0.86 \\
(0.10)\end{array}$ & $\begin{array}{c}-1.07 \\
(0.08)\end{array}$ & $\begin{array}{r}-1.20 \\
(0.06)\end{array}$ & $\begin{array}{c}-1.14 \\
(0.08)\end{array}$ & $\begin{array}{c}-0.76 \\
(0.07)\end{array}$ & $\begin{array}{l}+0.51 \\
(0.08)\end{array}$ \\
\hline $10^{\circ}$ & $\begin{array}{c}-0.48 \\
(0.10)\end{array}$ & $\begin{array}{c}-0.83 \\
(0.11)\end{array}$ & $\begin{array}{c}-1.11 \\
(0.06)\end{array}$ & $\begin{array}{c}-1.30 \\
(0.05)\end{array}$ & $\begin{array}{c}-1.21 \\
(0.06)\end{array}$ & $\begin{array}{r}-0.80 \\
(0.04)\end{array}$ & $\begin{array}{c}+0.51 \\
(0.10)\end{array}$ \\
\hline $15^{\circ}$ & $\begin{array}{r}-0.68 \\
(0.07)\end{array}$ & $\begin{array}{r}-0.92 \\
(0.08)\end{array}$ & $\begin{array}{c}-1.23 \\
(0.07)\end{array}$ & $\begin{array}{r}-1.36 \\
(0.06)\end{array}$ & $\begin{array}{c}-1.09 \\
(0.06)\end{array}$ & $\begin{array}{c}-0.70 \\
(0.05)\end{array}$ & $\begin{array}{l}+0.63 \\
(0.08)\end{array}$ \\
\hline
\end{tabular}

表 3 鋳造冠外形の寸法変化 (shoulder type)

\begin{tabular}{c|c|c|c|c|c|c|c}
\hline \hline 部位 & $\mathrm{a}$ & $\mathrm{b}$ & $\mathrm{c}$ & $\mathrm{d}$ & $\mathrm{e}$ & $\mathrm{f}$ & $\mathrm{g}$ \\
\hline 偭斜度 & -0.63 & -0.91 & -1.05 & -1.11 & -1.00 & -0.80 & +0.52 \\
$2^{\circ}$ & $(0.09)$ & $(0.07)$ & $(0.07)$ & $(0.07)$ & $(0.08)$ & $(0.06)$ & $(0.10)$ \\
\hline \multirow{2}{*}{$5^{\circ}$} & -0.71 & -1.01 & -1.21 & -1.25 & -1.12 & -0.76 & +0.61 \\
& $(0.06)$ & $(0.07)$ & $(0.07)$ & $(0.07)$ & $(0.06)$ & $(0.04)$ & $(0.09)$ \\
\hline \multirow{2}{*}{$10^{\circ}$} & -0.68 & -1.04 & -1.19 & -1.39 & -1.24 & -0.90 & +0.48 \\
& $(0.08)$ & $(0.10)$ & $(0.06)$ & $(0.07)$ & $(0.06)$ & $(0.05)$ & $(0.07)$ \\
\hline \multirow{2}{*}{$15^{\circ}$} & -0.74 & -1.11 & -1.25 & -1.36 & -1.20 & -0.91 & +0.58 \\
& $(0.10)$ & $(0.08)$ & $(0.06)$ & $(0.07)$ & $(0.07)$ & $(0.06)$ & $(0.09)$ \\
\hline
\end{tabular}

unit : \%

( ) : s.d.

よる変化が認められなかつた. 部位による変化について は，(b)または (c)で最も大きな収縮率を示し，(d), (e), (f) と歯頸部に近づくほどしだいに収縮率が 減少し，(f)に

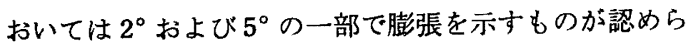
れた。 また，(f)においては，軸面傾斜度による外形の
寸法変化が最も著明に認められた。

chamfer type の場合には，表 2) および図14）に示 したように，冠上縁部 (a) は，0.48〜0.68\%の収縮を示 し軸面傾斜度による変化は認められなかつた。部位によ る変化については, 軸面傾斜度がいずれの場合にも, (b), 


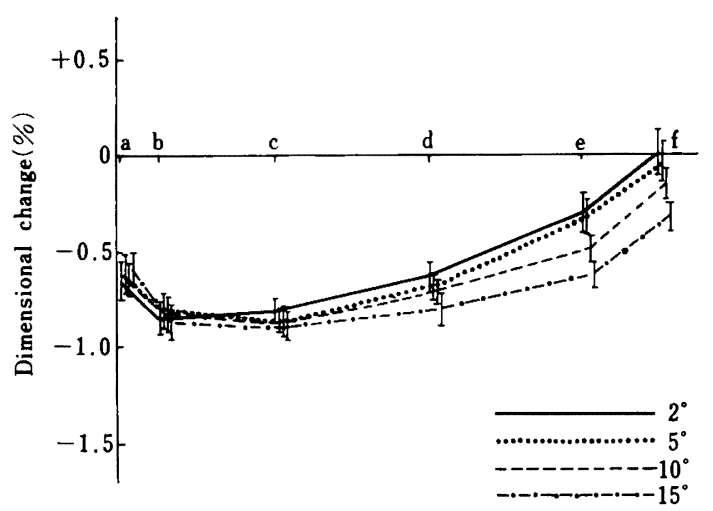

図13鋳造冠の幅についての測定部位による寸法変化 (knife edge type の場合)

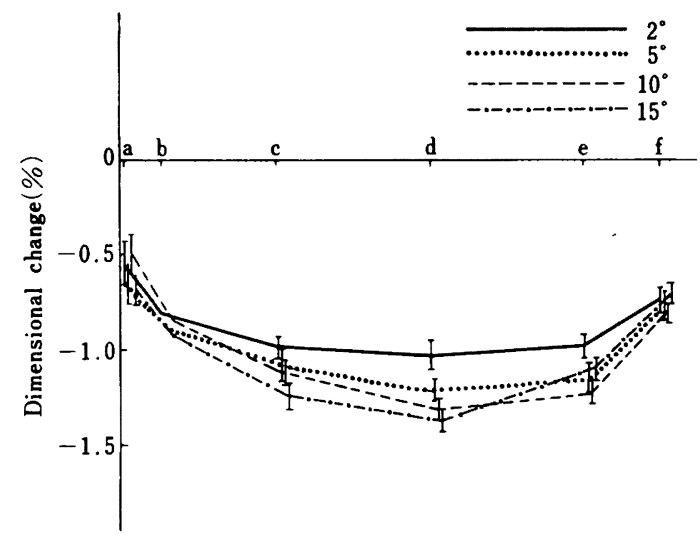

図14鋳造冠の幅についての測定部位による寸法変化 (chamfer type の場合)

(c)としだいに収縮率が大きくなり，(d)において最も大 きな収縮率を示し，かつ軸面傾斜度が大きいほど収縮率 が大きい傾向を示した，それに反し，(e),(f) と歯頸部に 至るほど収縮率はしだいに減少し，(f)においては軸面傾 斜度による変化は認められなかつた。

Shoulder type の場合には，表 3）および図15）に示 したように, chamfer type とほぼ同じ傾向が認められ た.

軸面傾斜度についてみると，たとえば $10^{\circ}$ の場合には 図16）に示したように(a), (b)においては, 辺縁形態によ る寸法変化の相異はほとんど認められなかつたが，(c)〜 (f)においては, knife edge type の収縮率が chamfer type, shoulder type にくらべて小さかつた.

\section{実験 II : 適合度}

適合度の結果を表 4) に示した. 表の值は, 口ウ型と 比較した鋳造冠の浮き上がり量を示し（一）の值は沈下 量を示す.

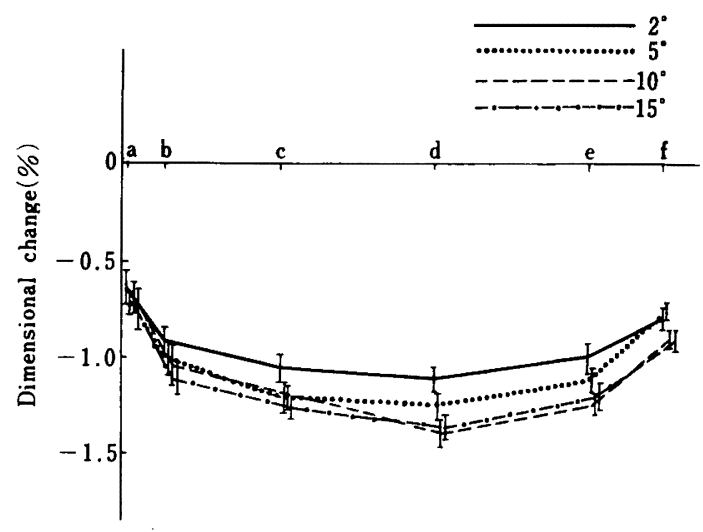

図15鋳造冠の幅についての測定部位による寸法変化 (shoulder type の場合)

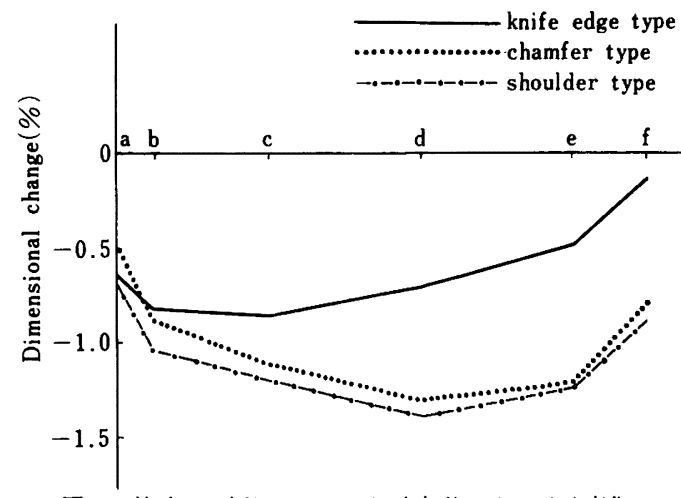

図16 鉡造冠の幅についての測定部位による寸法変化 （軸面傾斜度が $10^{\circ}$ の場合について）

表 4 適合度（浮き上がり）

\begin{tabular}{|c|c|c|c|c|}
\hline 支台形 & 加 重 & $400 \mathrm{~g}$ & $5 \mathrm{~kg}$ & $30 \mathrm{~kg}$ \\
\hline & $2^{\circ}$ & $101.8(33.4)$ & $-5.6(9.8)$ & -20.0 \\
\hline 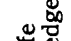 & $5^{\circ}$ & $39.4(15.8)$ & $-12.6(7.0)$ & $-23.8(5.0)$ \\
\hline 艺 & $10^{\circ}$ & $25.9(12.5)$ & $-10.7(4.0)$ & $-18.3(3.5)$ \\
\hline & $15^{\circ}$ & $17.5(7.3)$ & $-12.8(4.1)$ & $-22.3(3.0)$ \\
\hline & $2^{\circ}$ & $80.1(20.5)$ & $27.6(10.8)$ & $9.1(3.8)$ \\
\hline 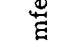 & $5^{\circ}$ & $36.6(8.1)$ & $18.2(4.1)$ & $5.0(3.4)$ \\
\hline 馬 & $10^{\circ}$ & $34.5(6.4)$ & $14.4(4.3)$ & $6.9(2.6)$ \\
\hline & $15^{\circ}$ & $24.7(4.6)$ & $12.6(3.5)$ & $3.7(2.9)$ \\
\hline & $2^{\circ}$ & $119.0(34.8)$ & $28.2(13.2)$ & $16.4(5.6)$ \\
\hline$\frac{0}{7}$ & $5^{\circ}$ & $41.3(11.5)$ & $18.6(4.3)$ & $10.5(2.5)$ \\
\hline 룽 & $10^{\circ}$ & $37.0(9.2)$ & $19.4(6.2)$ & $13.8(4.3)$ \\
\hline & $15^{\circ}$ & $30.1(8.5)$ & $18.1(7.4)$ & $12.3(5.8)$ \\
\hline
\end{tabular}




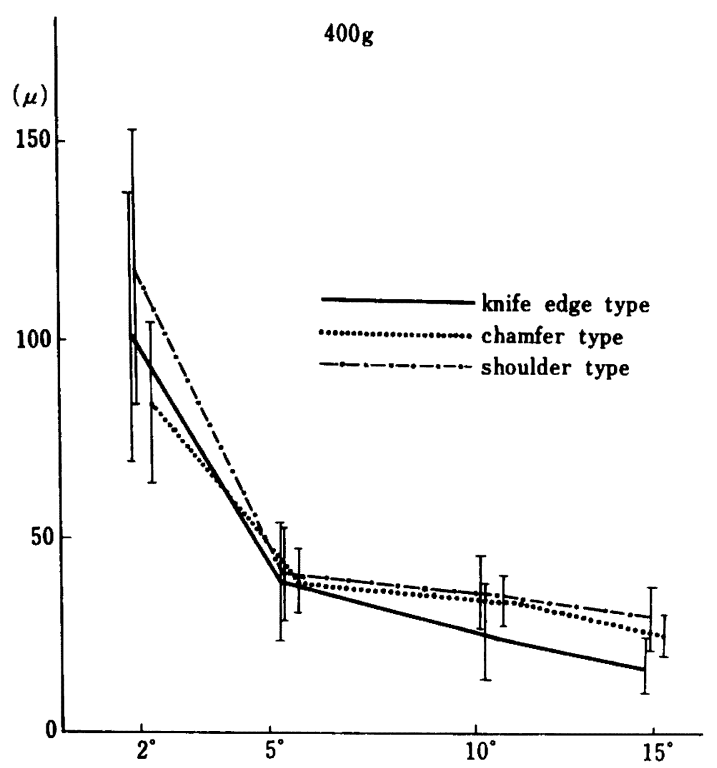

図17軸面傾斜度による適合度:の変化 (加重量が $400 \mathrm{~g}$ の場合)

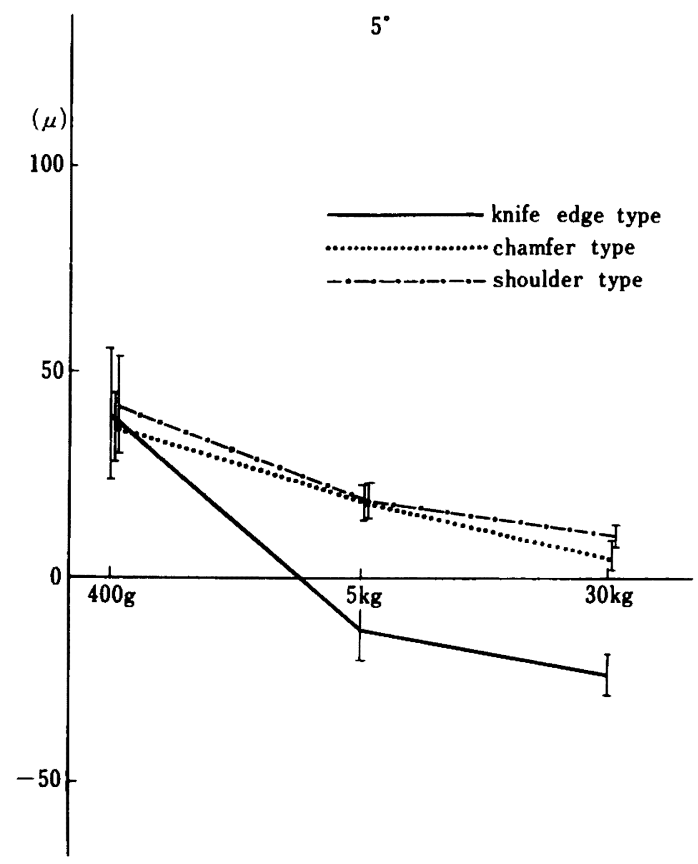

図18 加重量による適合度の変化 （軸面傾斜度が: $5^{\circ}$ の場合）

加重量が $400 \mathrm{~g}$ の場合の適合度は, 図17）に示したよ うに, 軸面傾斜度が $2^{\circ}$ の場合に $80 \sim 120 \mu$ の浮き上が りを示し, $5^{\circ}$ の場合の浮き上がり量は 36〜 41 $\mu$ であ

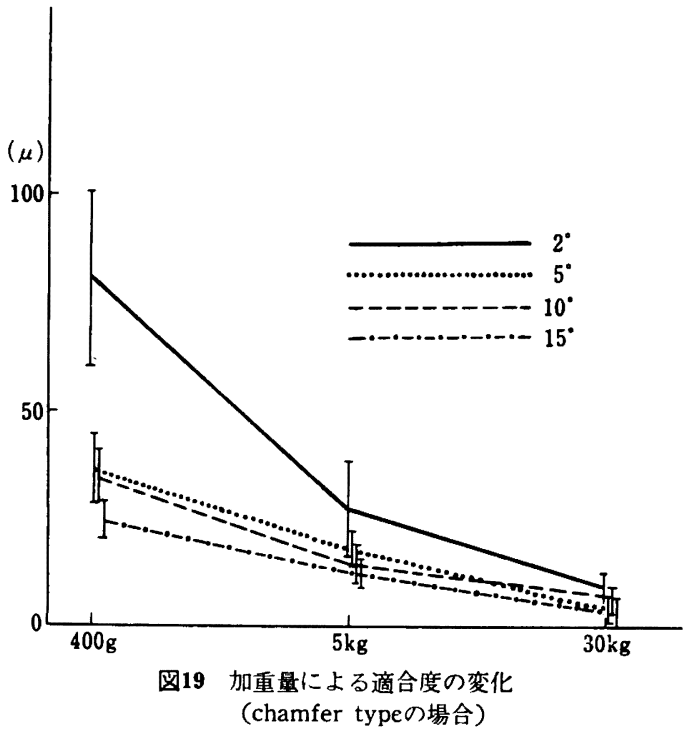

り, $2^{\circ}$ にくらべて急激な浮き上がり量の減少を示した. また， $5^{\circ}$ にくらべて $10^{\circ}, 10^{\circ}$ にくらべて $15^{\circ}$ と, 軸面 傾斜度が大きいほど浮き上がり量が小さくなる傾向を示 したが，5〜15における 適合度には著明な変化が認め られなかつた. なお, 加重量が $400 \mathrm{~g}$ の場合には, 蒾頸 部辺粶形態による適合度の変化はほとんど認められなか つた.

加重量が変化した場合には，たとえば図18）は軸面傾 斜度が $5^{\circ}$ における適合度を示したものである. 辺縁形 態が knife edge type の場合には, $5 \mathrm{~kg}$ および $30 \mathrm{~kg}$ の加重により, 鋳造冠はロウ型にくらべて沈下を示し, chamfer type および shoulder type の適合度との間に 有意差を示した.

また, 図 19) は辺縁形態が chamfer type の場合に おける鋳造冠の適合度を図示したものである. 加重量が $5 \mathrm{~kg}$ の場合には, 軸面傾斜度が $2^{\circ}$ の鋳造冠の適合度 は, $5^{\circ}, 10^{\circ}, 15^{\circ}$, にくらべてやや大きな浮き上がりを 示したが, 加重量が $30 \mathrm{~kg}$ の場合には, 軸面傾斜度によ る適合度の変化はほとんど認められなかつた。

\section{実験 III：セメント合着による浮き上がり}

セメント合着による浮き上がり量の結果を表 5 ）に示 した. 表の值は, $30 \mathrm{~kg}$ 加重による鋳造冠試適時の支台 歯と鋳造冠の距離にくらべて，七メント合着したため増 加した支台歯と鋳造冠の距離をあらわす.

結果をグラフに示すと図20）となり，七メント合着に よる浮き上がり量は, 軸面傾斜度が $2^{\circ}$ の場合に 500 $1,000 \mu$ と最も大きな值を示し, $5^{\circ}$ の場合には $2^{\circ} に く$ 


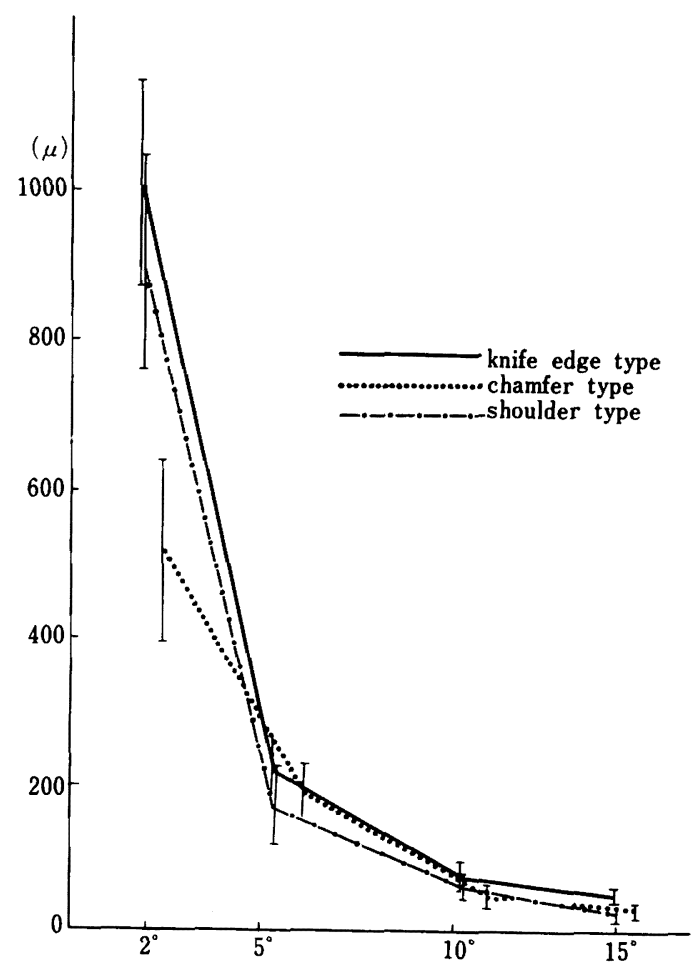

図20軸面傾斜度によるセメント合着 浮き上がり量の変化

表 5 セメント合着による浮き上がり

\begin{tabular}{r|c|c|c}
\hline $\begin{array}{r}\text { 辺緑 } \\
\text { 傾斜度 }\end{array}$ & $\begin{array}{c}\text { knife edge } \\
\text { type }\end{array}$ & $\begin{array}{c}\text { chamfer } \\
\text { type }\end{array}$ & $\begin{array}{c}\text { shoulder } \\
\text { type }\end{array}$ \\
\hline $2^{\circ}$ & $\begin{array}{c}1027.3 \\
(136.6)\end{array}$ & $\begin{array}{c}502.7 \\
(118.0)\end{array}$ & $\begin{array}{c}907.2 \\
(140.2)\end{array}$ \\
\hline $5^{\circ}$ & $\begin{array}{c}221.4 \\
(38.6)\end{array}$ & $\begin{array}{c}197.3 \\
(34.1)\end{array}$ & $\begin{array}{c}166.4 \\
(45.8)\end{array}$ \\
\hline $10^{\circ}$ & $\begin{array}{c}(10.0 \\
(17.6)\end{array}$ & $\begin{array}{c}50.0 \\
(15.2)\end{array}$ & $\begin{array}{c}66.4 \\
(13.4)\end{array}$ \\
\hline $15^{\circ}$ & 53.6 & 34.8 & 29.2 \\
& $(9.5)$ & $(4.4)$ & $(3.8)$ \\
\hline
\end{tabular}

らべて急激な減少を示し, $10^{\circ}$ の場合には $5^{\circ}$ にくらべ て減少するがその程度は小さくなり, $10^{\circ}$ と $15^{\circ}$ では著 明な変化は認められなかつた。

歯頸部辺縁形態が浮き上がり量に及ぼす影響に関して は, knife edge type の浮き上がり量は, chamfer type および shoulder type にくらべてやや大きくなる傾向 を示したが，著明な変化は認められなかつた。
表 6 切断面におけるセメント層の厚さ（knife edge type）

\begin{tabular}{r|c|c|c|c}
\hline $2^{\circ}$ & $\mathrm{A}$ & $\mathrm{B}$ & $\mathrm{C}$ & $\mathrm{D}$ \\
\hline $5^{\circ}$ & $\begin{array}{c}1030.9 \\
(135.8)\end{array}$ & $\begin{array}{c}26.0 \\
(5.2)\end{array}$ & $\begin{array}{c}38.2 \\
(8.9)\end{array}$ & $\begin{array}{c}52.8 \\
(13.1)\end{array}$ \\
\hline & $\begin{array}{c}235.1 \\
(44.3)\end{array}$ & $\begin{array}{c}22.6 \\
(5.3)\end{array}$ & $\begin{array}{c}34.6 \\
(4.7)\end{array}$ & $\begin{array}{c}42.5 \\
(10.5)\end{array}$ \\
\hline $10^{\circ}$ & $\begin{array}{c}100.4 \\
(9.2)\end{array}$ & $\begin{array}{c}17.4 \\
(3.8)\end{array}$ & $\begin{array}{c}22.3 \\
(4.7)\end{array}$ & $\begin{array}{c}25.4 \\
(6.4)\end{array}$ \\
\hline $15^{\circ}$ & $\begin{array}{c}68.2 \\
(9.6)\end{array}$ & $\begin{array}{c}16.3 \\
(4.2)\end{array}$ & $\begin{array}{c}19.6 \\
(4.1)\end{array}$ & $\begin{array}{c}19.5 \\
(3.4)\end{array}$ \\
\hline & & & \multicolumn{2}{c}{ unit : $\mu$} \\
\end{tabular}

表 7 切断面におけるセメント層の厚さ (chamfer type)

\begin{tabular}{|c|c|c|c|c|c|}
\hline $\begin{array}{l}\text { 部位 } \\
\text { 傾斜度 }\end{array}$ & A & B & C & $\mathrm{D}$ & $\mathrm{E}$ \\
\hline $2^{\circ}$ & $\begin{array}{c}536.9 \\
(113.4)\end{array}$ & $\begin{array}{l}24.1 \\
(8.6)\end{array}$ & $\begin{array}{l}26.4 \\
(4.0)\end{array}$ & $\begin{array}{l}24.3 \\
(2.9)\end{array}$ & $\begin{array}{l}353.8 \\
(58.9)\end{array}$ \\
\hline $5^{\circ}$ & $\begin{array}{c}219.0 \\
(37.6)\end{array}$ & $\begin{array}{l}22.8 \\
(1.9)\end{array}$ & $\begin{array}{l}24.8 \\
(4.9)\end{array}$ & $\begin{array}{l}21.3 \\
(4.0)\end{array}$ & $\begin{array}{l}138.0 \\
(11.5)\end{array}$ \\
\hline $10^{\circ}$ & $\begin{array}{c}80.9 \\
(11.6)\end{array}$ & $\begin{array}{l}18.5 \\
(3.5)\end{array}$ & $\begin{array}{l}17.3 \\
(0.8)\end{array}$ & $\begin{array}{l}17.1 \\
(0.7)\end{array}$ & $\begin{array}{c}48.1 \\
(10.8)\end{array}$ \\
\hline $15^{\circ}$ & $\begin{array}{c}64.9 \\
(\quad 7.3)\end{array}$ & $\begin{array}{l}18.1 \\
(2.1)\end{array}$ & $\begin{array}{l}18.5 \\
(4.3)\end{array}$ & $\begin{array}{l}17.8 \\
(4.3)\end{array}$ & $\begin{array}{c}29.8 \\
(2.8)\end{array}$ \\
\hline
\end{tabular}

表 8 切断面におけるセメント層の厚さ（shoulder type）

\begin{tabular}{|c|c|c|c|c|c|}
\hline $\begin{array}{l}\text { 部位 } \\
\text { 傾斜度 }\end{array}$ & A & B & $\mathrm{C}$ & $\mathrm{D}$ & $\mathrm{E}$ \\
\hline $2^{\circ}$ & $\begin{array}{c}940.9 \\
(140.3)\end{array}$ & $\begin{array}{l}25.1 \\
(8.1)\end{array}$ & $\begin{array}{l}25.4 \\
(6.6)\end{array}$ & $\begin{array}{l}23.8 \\
(4.8)\end{array}$ & $\begin{array}{c}925.5 \\
(138.5)\end{array}$ \\
\hline $5^{\circ}$ & $\begin{array}{c}220.2 \\
(44.4)\end{array}$ & $\begin{array}{l}21.7 \\
(4.6)\end{array}$ & $\begin{array}{l}23.2 \\
(2.3)\end{array}$ & $\begin{array}{l}25.0 \\
(2.5)\end{array}$ & $\begin{array}{c}194.1 \\
(44.1)\end{array}$ \\
\hline $10^{\circ}$ & $\begin{array}{c}100.4 \\
(17.2)\end{array}$ & $\begin{array}{l}19.2 \\
(1.4)\end{array}$ & $\begin{array}{l}20.8 \\
(2.8)\end{array}$ & $\begin{array}{l}17.5 \\
(1.5)\end{array}$ & $\begin{array}{c}78.4 \\
(17.4)\end{array}$ \\
\hline $15^{\circ}$ & $\begin{array}{r}66.0 \\
(\quad 8.6)\end{array}$ & $\begin{array}{l}15.3 \\
(2.6)\end{array}$ & $\begin{array}{l}16.7 \\
(1.6)\end{array}$ & $\begin{array}{l}17.0 \\
(2.9)\end{array}$ & $\begin{array}{c}42.6 \\
(\quad 3.4)\end{array}$ \\
\hline
\end{tabular}

実験 IV: 切断面のセメント層

各部位 $(\mathrm{A})$ ～(E) におけるセメント層の厚さの結果を表 $6,7,8)$ に示した.

天蓋部(A)のセメント層の厚さは, セメント合着によ る浮き上がり量にくらべてやや大きな值を示し, 支台歯 


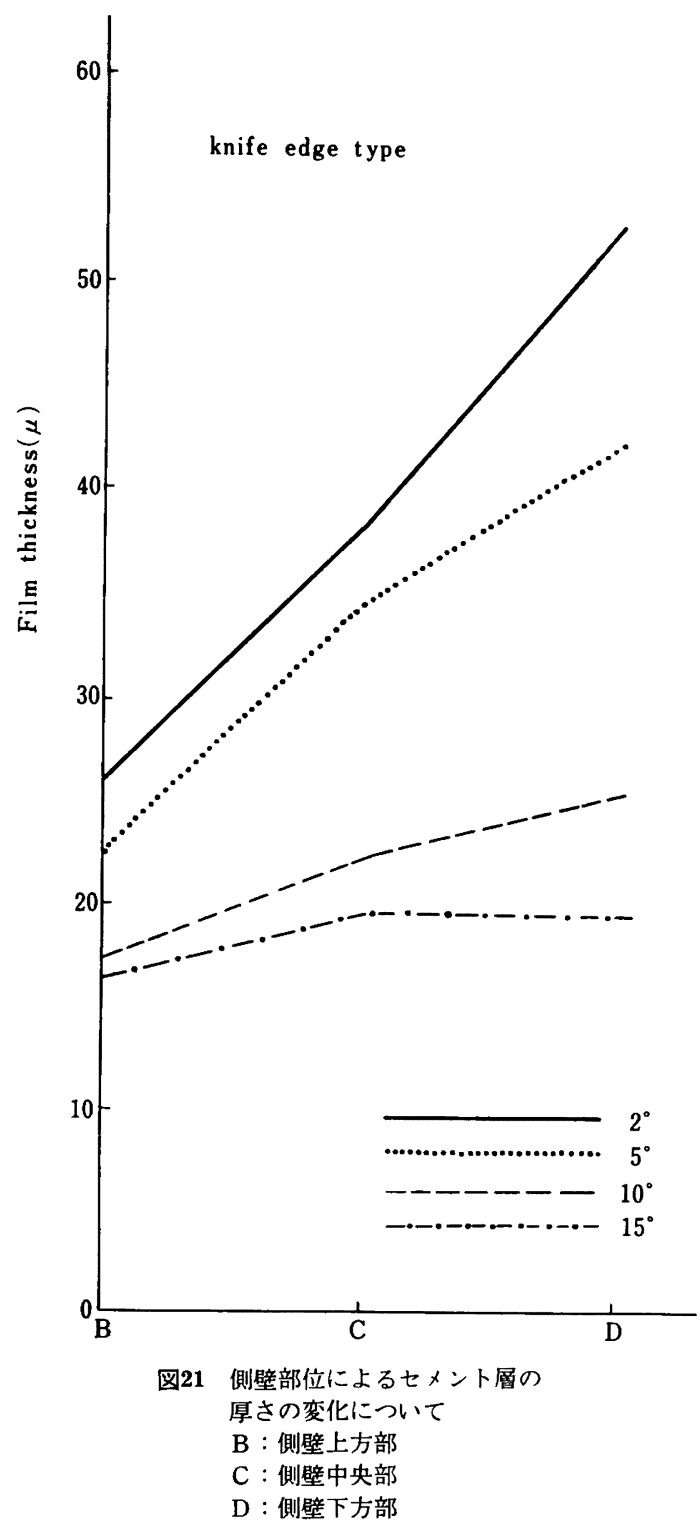

形態による恋化は同じ傾向を示した.

側壁部 (B)〜(D)のセメント層の厚さについてみてみる と, knife edge type の場合には, 表 6 ), 図21）に示 したように, 軸面傾斜度が大きくなるほどセメント層は 薄くなり，部位による変化は $(\mathrm{B})<(\mathrm{C})<(\mathrm{D})$ の関係を示し， この変化は軸面傾斜度が小さいほど著明であつた。

Chamfer type の場合には，表 7)，図22）に示した ように，側壁セメント層の厚さは，軸面傾斜度が大きく なるほど小さくなる傾向を示したが, 部位による変化は

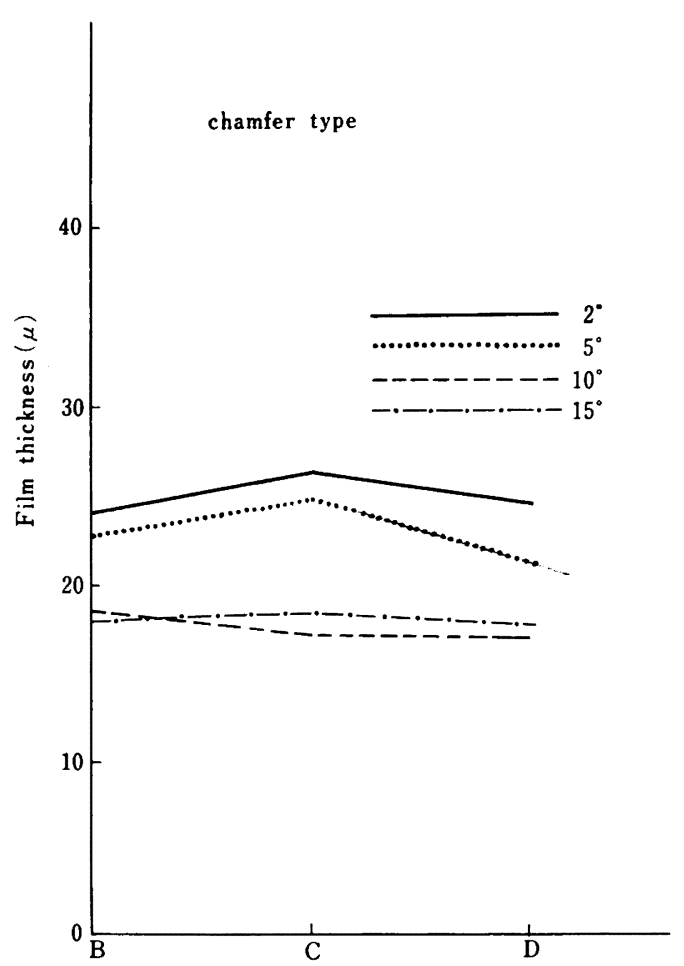

図22側壁部位によるセメント層の

厚さの変化について

$\mathrm{B}$ ：側壁上方部

C：側壁中央部

D：側壁下方部

表 9 歯頸部辺縁のセメント層の厚さ

\begin{tabular}{|c|c|c|c|}
\hline $\begin{array}{c}\text { 辺緑 } \\
\text { 形態 } \\
\text { 傾斜度 }\end{array}$ & $\begin{array}{c}\text { knife edge } \\
\text { type }\end{array}$ & $\begin{array}{c}\text { chamfer } \\
\text { type }\end{array}$ & $\begin{array}{c}\text { shoulder } \\
\text { type }\end{array}$ \\
\hline $2^{\circ}$ & $52.8 \mu$ & $353.8 \mu$ & $925.5 \mu$ \\
\hline $5^{\circ}$ & 42.5 & 138.0 & 194.1 \\
\hline $10^{\circ}$ & 25.4 & 48.1 & 78.4 \\
\hline $15^{\circ}$ & 19.5 & 29.8 & 42.6 \\
\hline
\end{tabular}

ほとんど認められなかつた. また, shoulder type の場 合には, 表 8), 図23）に示したように, chamfer type と同じ傾向が認められた。

歯頸部辺縁のセメント層に関しては，表 9）に示した ように，支台歯形態により著明な変化が認められた．軸 面傾斜度についてみてみると, セメント層の厚さは, $2^{\circ}>5^{\circ}>10^{\circ}>15^{\circ}$ の関倸を示し, 軸面傾斜度による变 
表10 軸面㑯斜度が変化した場合の鋳造冠の 引張り強さ (knife edge type)

\begin{tabular}{c|c|c|c|c|c}
\hline \hline No. & $2^{\circ}$ & $5^{\circ}$ & $10^{\circ}$ & $15^{\circ}$ & $\begin{array}{l}\text { pin. } \\
\text { ledge }\end{array}$ \\
\hline 1 & $(60.8)$ & 28.7 & 17.4 & 11.4 & 18.9 \\
2 & $(54.6)$ & 37.2 & 21.3 & 17.5 & 19.0 \\
3 & 79.2 & 32.1 & 29.5 & 13.3 & 10.7 \\
4 & $(47.0)$ & 36.5 & 15.8 & 17.7 & 20.5 \\
5 & $(57.5)$ & $(24.0)$ & 25.4 & 16.8 & 17.1 \\
6 & $(48.0)$ & 35.7 & 27.2 & 13.8 & \\
\hline Ave. & 79.2 & 34.0 & 22.8 & 15.1 & 17.2 \\
(s. d.) & & $(3.5)$ & $(5.0)$ & $(2.6)$ & $(3.8)$ \\
\hline & & \multicolumn{3}{|c}{ unit : kg } \\
\end{tabular}

表11歯頸部辺縁形態が変化した場合の 鋳造冠の引張り強さ $\left(10^{\circ}\right)$

\begin{tabular}{c|c|c|c}
\hline $\begin{array}{r}\text { 辺緑 } \\
\text { No. }\end{array}$ & $\begin{array}{c}\text { knife edge } \\
\text { type }\end{array}$ & $\begin{array}{c}\text { chamfer } \\
\text { type }\end{array}$ & $\begin{array}{c}\text { shoulder } \\
\text { type }\end{array}$ \\
\hline 1 & 17.4 & 20.2 & 25.3 \\
2 & 21.3 & 22.5 & 29.0 \\
3 & 29.5 & 19.7 & 18.2 \\
4 & 15.8 & 16.2 & $(18.5)$ \\
5 & 25.4 & 25.8 & 21.0 \\
6 & 27.2 & 18.7 & 17.6 \\
\hline Ave. & 22.8 & 20.5 & 22.2 \\
(s. d.) & $(5.0)$ & $(3.0)$ & $(4.3)$ \\
\hline & & & unit : $\mathrm{kg}$ \\
& & & $($ ) : 破折
\end{tabular}

化は shoulder type の場合に最も著明に認められた，辺 縁形態についてみてみると,セメント層の厚さは, knife edge type $<$ chamfer type $<$ shoulder type の関係を示 し，かつ軸面傾斜度が小さいほど著明な変化が認められ た.

\section{実験 $\mathbf{V}:$ 保持力}

引張り強さの測定結果を表10，11）および図24）に示 した.

軸面傾斜度についてみてみると, 表10）に示したよう に, 鋳造冠の引張り強さは, $2^{\circ}$ の場合に最も大きな值 を示し, $2^{\circ}>5^{\circ}>10^{\circ}>15^{\circ}$ の関係となり，各々の間に 有意差が認められた.

歯项部辺縁形態についてみてみると，表11）に示した ように, 鋳造冠の引張り強さは, knife edge type の場 合に $22.8 \mathrm{~kg}$, chamfer type の場合に $20.5 \mathrm{~kg}$, shoulder type の場合に $22.2 \mathrm{~kg}$ となり， 3 者の間に有意差 が認められなかつた。

なお，ピンレッヂの引張り強さは, $17.2 \mathrm{~kg}$ の值を示

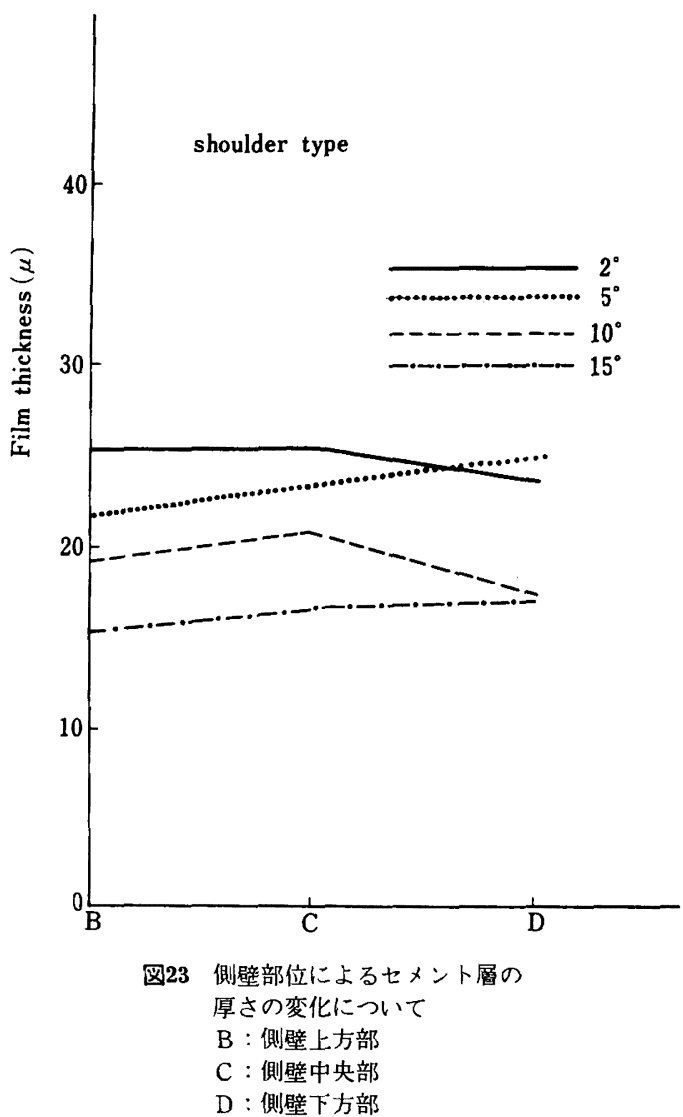

し, 軸面傾斜度が $15^{\circ}$ の鋳造冠の引張り強さよりやや大 きな値を示したが，両者の間に有意差は認められなかつ た.

\section{考察}

鋳造冠を製作するにあたつて，支台歯形成から始を り, 印象採得, 模型製作, 口ウ型採得, 鋳造, 研磨, 装 着に至るまでの一連の操作過程において，鋳造冠の各種 条件，たとえば適合度をたは保持力などに影響を及ぼす 因子が数多く挙げられる.

中村 ${ }^{111}$ は，一連の操作過程に品質管理の概念をとり入 れ, 多くの因子をコントロールして総合的な検討を加え ることにより，より良き鋳造冠を製作することができる と述べている，このような考えにしたがい，畑 ${ }^{12)}$ は印 象採得から鋳造までの諸因子が鋳造冠の適合度に及ぼす 影響について検討した。

一方，鋳造冠に必要な条件としては，正しい形態の回 


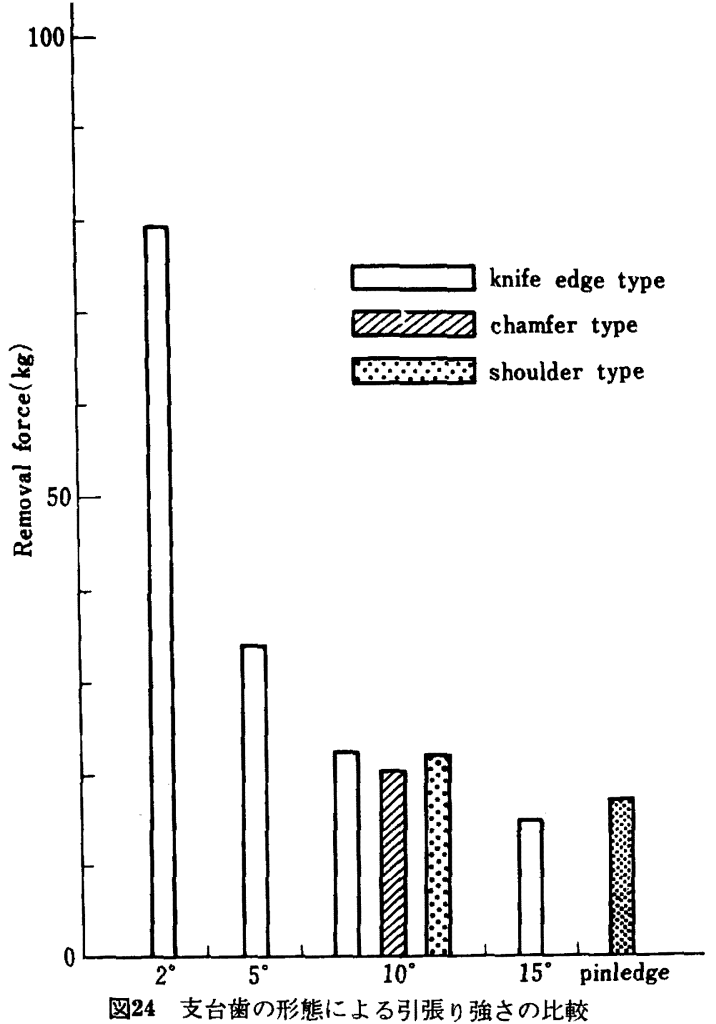

復が行なわれていること, 適合度が良いこと, セメント 合着による浮き上がりが少ないこと，歯顓部のセメント 層が小さいこと, 保持力が十分であることなどが挙げら れる。これらの条件をすへて満たした鋳造冠の製作が望 ましいが，たとえば，適合の良い鋳造冠はセメント合着 による浮き上がりが大きくなる13 15) など相反する条件 があるため，鋳造冠製作過程における因子を検討するに あたり，鋳造冠の各種条件に及ぼす影響を同時にとら え, 補経学的な立場から総合的な検討を加える必要があ る.しかし、このような観点から，鋳造冠の製作過程に お汭因子について検討した研究報告はみられない．

ところで，鋳造冠の製作過程にお於る操作のなかで も, 支台歯形成は, その出発点であり, 印象採得以後の 操作に影響を及ぽすのみならず，鋳造冠の各種条件に対 して影響を及ぼすと考えられ，補緅を行なうにあたりと くに重要な臨床的操作である.

支台㧘形成に扔いては, 切削用具, 方法の選択, 歯肉

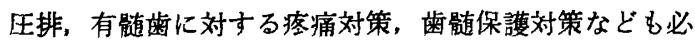
要であるが，とりわけ支台歯形態を決めることが重要で ある.
表12 接触点部の収縮量について

\begin{tabular}{r|c|c|c}
\hline $\begin{array}{r}\text { 迩緑 } \\
\text { 傾斜度 }\end{array}$ & $\begin{array}{c}\text { knife edge } \\
\text { type }\end{array}$ & $\begin{array}{c}\text { chamfer } \\
\text { type }\end{array}$ & $\begin{array}{c}\text { shoulder } \\
\text { type }\end{array}$ \\
\hline $2^{\circ}$ & $\begin{array}{c}30.0 \\
(5.3)\end{array}$ & $\begin{array}{l}37.1 \\
(6.5)\end{array}$ & $\begin{array}{c}39.4 \\
(6.3)\end{array}$ \\
\hline $5^{\circ}$ & 31.8 & 41.3 & 45.2 \\
& $(4.8)$ & $(6.4)$ & $(6.4)$ \\
\hline $10^{\circ}$ & 32.1 & 42.3 & 44.6 \\
& $(6.2)$ & $(4.8)$ & $(4.9)$ \\
\hline $15^{\circ}$ & 33.0 & 46.2 & 46.8 \\
& $(6.1)$ & $(6.3)$ & $(4.9)$ \\
\hline
\end{tabular}

支台㐘形態は, 咬合面形態, 軸面形態および歯频部辺 縁形態に分けられるが，これらの因子のなかでも，軸面 傾斜度ならびに莼頸部辺縁形態は互いに関連があり，鋳 造冠への影響に関して重要な要素である.

軸面傾斜度に関しては, 従来, 帯環金属冠に扔ける支 台歯形成の概念から，アンダーカットのない上うに上方 にややテーパーをつけ, 通常 $2^{\circ} \sim 5^{\circ}$ が適当であるとさ れている13 16)。しかし，臨床においては，軸面傾斜度 が小さく，かつアンダーカットを生じないように軸面形 成を行なうのがむずかしいのみならず，多数歯にわたる 鋳造架工義歯を行なら場合には，個々の支台歯の軸面傾 斜度を小さくし，かつ各支台歯間に平行性をあたえるこ とがむずかしいため，架工義歯の装着が困難になりやす い，また，支台歯が傾斜している場合には，咬合関倸の 改良, あるいは他の支台歯との平行性を与えるために, 大きな軸面傾斜度を付与した支台歯形成が必要である. 最近, 鋳造冠の支台歯形成について, 軸面傾斜度は $2^{\circ} \sim$ $10^{\circ}{ }^{17)}$ ， あるいは $5^{\circ} \sim 20^{\circ}{ }^{18)}$ が適当であるという報告も みられるが，実験的裏付けに乏しいので，軸面傾斜度が 鋳造冠の各種条件に及ぼす影響を検討して決めるべきで あると考えられる。

歯頸部辺粶形態に関しては, knife edge type, chamfer type, shoulder type など多くの種類が 報告されて おり，臨床において種々の形態が要求され，かつ使用さ れている. しかし，歯頸部辺縁形態が鋳造冠の各種条件 に及ぼす影響についての報告 ${ }^{6}$, 19) は少なく，軸面傾斜 度と歯頸部辺縁形態の関連性について検討した研究はみ られない、このような意味合いから, 本研究は, 支台歯 の軸面傾斜度ならびに歯頸部辺縁形態が鋳造冠のもつ各 種条件に及ぼす影響を明らかにしようとしたものであ り，以下外形の寸法変化，適合度，セメント合着による 
浮き上がり, セメント層の厚さ, 保持力について考察を 行なう.

\section{外形の寸法変化について}

正しい形態の回復は, 鋳造冠の所要条件のひとつであ り，正しい形態が回復されていない場合には種々の障害 が起こる.すなわち, 咬合面の形態が悪い場合には咀囉 能率の低下を招き15)，側壁部の形態が悪い場合には歯肉 の損傷や退縮をおこし20,21)，咬合高径の回復が不良な場 合には歯根膜の損傷のため歯牙の動摇を誘発する22,23).

さらに，隣在歯との接触形態が不良な場合には，食物の 停滞をおこし，二次ウ蝕および歯周疾患などを誘発す $3^{24,25)}$.

咬合面の形態扔よび側壁の膨隆形態に関し， ロ ウ型採 得時にいかに正しい形態の回復を行なつたとしても， wax を金属に置き換える 鋳造操作を行なう以上，鋳造 による外形の寸法変化が起こると考えられる. そこで, 鋳造によつてどのような変化が起こるのか, そして支台 歯形態の差異が寸法変化にどのような影響を及ぼすかを 知る必要がある,

咬合関係に影響を及ぼす 長軸方向すなわち $(\mathrm{g})$ の寸法 変化は表 1，2，3）に示したごとく，0.5〜0.7\%すなわ ち $37 \sim 53 \mu$ の膨張を示し, 支台歯形態による変化は認 められなかつた.

隣在歯との接触関係に影響を及ぽすと考えられる部位 (c)の寸法変化について, 片側の隣接面における収縮量 は, 表12)のようになり, knife edge type, chamfer type, および shoulder type において，それぞれ30〜 $33 \mu, 37 \sim 46 \mu$, および 39〜47 $\mu$ の值を示し, knife edge type にくらべて chamfer type および shoulder type の収縮量が大きく，軸面傾斜度が大きいほど収縮 量も大きくなる傾向が認められた.

実験結果からもわかるように, 鋳造冠の長軸方向には すべて膨張を示し，横軸方向にはほとんどの場合に収縮 を示した. このことに関して考察してみると, 横軸方向 においては，埋没材の膨張がリングにより抑制されたた めと考えられる.すなわち, 著者はアスベストリボンの 裏装による影響を検討するため次のような予備実験を行 なつた。 直径 $10 \mathrm{~mm}$, 厚さ $3 \mathrm{~mm}$ の円板状のロウ型の側 壁にスプルー線を植立し, 本実験と同じ条件で埋没, 鋳 造を行なつたが, アスベストリボンの裏装を 1 枚から 6 枚 ( 1 枚: $0.4 \mathrm{~mm}$ ) に変化させて鋳造体を製作し, 口 ウ型と鋳造体の大きさを比較した. その結果, リング方 向の寸法変化は, アスベストリボンを 1 枚裏装した場合 に，0.96〜1.15\%の収縮を示し，アスベストリボンを増
加することにより漸次収縮率が小さくなる効果を認めた が，3枚〜 6枚においては有意差を認めず，依然とし て，0.35〜0.58\%の収縮を示した.

一方, リングの縦軸方向では, アスベストリボンを 3 枚〜 6 枚裏装した場合に，すべて 0.5〜0.9\%の膨張を 示した. また,この場合, 両者の中間である斜め方向に おいては，ほとんど膨縮を示さず，1％以下の膨張また は収縮を示した.このことから、アスベストリボンの裏 装を行なえばリングによる埋没材の膨張抑制をある程度 防ぐことはできるが, リングを使用するかぎり, リング による膨張抑制を完全に防ぐことはできないと考えられ る.この点に関して, 河野ら 26), 山根ら27)も, 埋没材の 膨張がリングにより抑制されたと報告している.

予備実験の結果を参考にして, 本実験では 4 枚のアス ベストリボンを裹装したが, 鋳造冠長軸方向にそつて, ロウ型の天蓋中央部にスプルー線を植立したため, 鋳造 冠外形寸法は長軸方向に膨張し, 横軸方向に収縮を示し たものと考えられる.

次に, 支台歯形態の差異により，鋳造冠横軸方向の寸 法が変化した原因について考察する.鋳造冠の側壁部 (c) 〜 f)における寸法変化は, knife edge type の場合に, chamfer type および shoulder typeにくらべて, 収縮 率が小さくなつた. さらに, 実験IV) の結果にみられた ように, knife edge type の側壁下方部のセメント層の 厚さは, chamfer type および shoulder type のそれに くらべて大きいことが認められた. これは, 外形寸法に おいてのみならず, 内側の寸法においても knife edge type の側壁下方部の寸法は, chamfer type および shoulder type にくらべて大きくなつたことを示してい る.この原因としては，表 13）に示したように，knife edge type の側壁肉厚が小さいためと考えられる.すな わち, 口ウ型の肉厚が小さい場合には, 口ウ型を支台歯 からはずす場合に変形を起こしやすく, ロウ型を埋没し た時埋没材の硬化膨張により変形を起こしやすい．およ び鋳型に鋳込まれた金属が凝固収縮を起こす時に埋没材 によつて収縮が妨げられるなどが考えられる。これらに

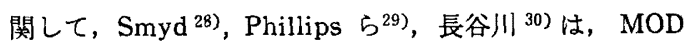
型インレ一, 鋳造冠などの外側性のロウ型を埋没した場 合には, 埋没材の硬化膨張によつてロウ型に変形が起こ り,ことにロウ型が薄い場合にはいつそう変形が起こり やすいと述べている，また，上新らは31,32)，埋没材の圧 縮強度が大きいほど鋳造冠の適合度が良くなり, その原 因としては，埋没材によつて金属の凝固収縮が抑制され るためであろうと報告している.すなわち、これは，金 
表13 knife edge type における鋳造冠側壁の肉厚

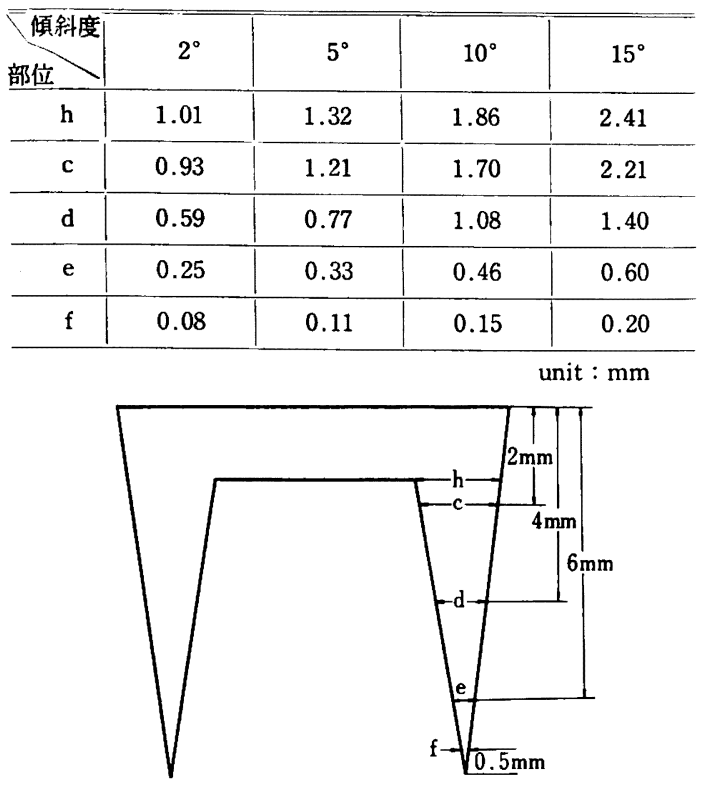

属の收縮による圧力と埋没材の圧縮抵抗とのバランスに より収縮が抑制されることを意味するので同一埋没材を 使用した時は，口ウ型の肉厚が小さいほど収縮による圧 力が小さくなり，收縮がいつそう抑制されるものと推定 できる.これらの原因がかさなり，総合的な 結果とし て肉厚の小さな部位の寸法は肉厚の大きな部位の寸法に くらべて大きくなつたものと考えられる.

以上のように，鋳造冠の外形寸法とくに接触点部の寸 法変化に関しては，接触点部の肉厚が小さくなるような 支台歯形態が良いと考えられる。一方，鋳造を行なつた 修復物は，装着する前に研磨を行なうものであり，研磨

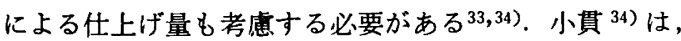
鋳造体を注意深く研磨すれば，仕上げ量は 24〜70 $\mu$ で あつたと報告している，前述したように，鋳造による接 触点部の寸法変化は支台歯形態により異なるが，30〜 $50 \mu$ の収縮を示していた.このように，鋳造による寸 法変化，および研磨による寸法変化はともに接触点部の 寸法を減少させるので,接触点部の形態回復に際しては, 口ウ型採得後, 接触点部にロウを盛り上げる方法 ${ }^{35}$ 37) などによつて, やや大きな鋳造冠を製作し, 口腔内試適 時に調整を行なう必要がある。そして，この場合，肉厚 が大きくなる支台歯形態の口ウ型は鋳造による収縮量が 大きくなることを考虑すべきである.

\section{適合度について}

従来,クラウン形態の鋳造体における適合度を測定す
る場合, shoulder type の鋳造冠を使用して, shoulder 部における鋳造冠と支台歯の間隙を測定し適合度の判定 を行なつている2,38)。 従来の測定方法では knife edge type の鋳造冠の適合度を測定することができない．ま た，鋳造冠の歯頸部辺縁を拡大して観察した場合に，鋳 造冠の辺縁が鋸歯状を呈することがあり，正確な間隙量 を測定するのが困難になりやすく，鋳造冠を支台歯に試 適した場合に，浮き上がりを生じている場合でも間隙と して測定できなかったりする欠点がある.そこで本研究 においては, 支台歯と口ウ型, および支台歯と鋳造冠の 距離を測定し, 両者を比較することにより, 浮き上がり 量をたは沈下量を求め, 鋳造冠の適合度の判定を行なつ た.この判定方法によれば, shoulder type の鋳造冠に おいて, 外観上 frictional fit を呈し, 歯頸部にほとん ど間隙を認めず，鋳造冠は浮き上がっていないと考えら れる場合でも，測定すれば鋳造冠が浮き上がつていると いう結果を得ることがあり, 従来の方法よりも正確な適 合度の判定ができる方法であるといえる.

鋳造冠の適合度に影響を及ぼす因子としては，鋳造冠 自体からみると，鋳造収縮および内面のアラサが挙げら れる. 吉田 ${ }^{38)}$ は, 鋳造冠の歯頸部における間陌量を測定 して，鋳造冠の収縮率を求めたところ，それらは金属の 種類によつて異なつたと報告している. また， 総山 ${ }^{39)}$ は, 金属の種類ならびに鋳造体の形態すなわちインレ 一，鋳造冠などによつて，鋳造体の収縮率が異なること を指摘し，それぞれの収縮率を求めて，鋳造体の適合度 を良くするための鋳造方法について検討している．

一方, 鋳造冠の適合度に関して, 臨床において要求さ れるのは，鋳造冠の收縮率ではなく，実際に口腔内に試 適した場合に生じる浮き上がり量である．鋳造冠を試適 して，手指によりかるく圧迫した状態が 想定される 400 gの加重を行なつた場合の鋳造冠の適合度は，表 4）に 示したように，軸面傾斜度が $2^{\circ}$ の場合に $80 \sim 120 \mu$ の 浮き上がりを示し， $5^{\circ}, 10^{\circ}$ ，および $15^{\circ}$ の場合に，そ れぞれ 36〜41 $\mu, 25 \sim 37 \mu$ および 17〜30 $\mu$ の浮き上 がりを示した，ところで，これらの浮き上がり量から鋳 造冠の収縮率を下記の式によつて求めてみると，

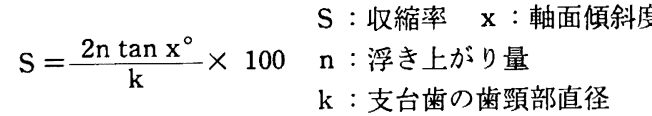

たとえば, shoulder type において, 軸面傾斜度が $2^{\circ}$, $5^{\circ}, 10^{\circ}, 15^{\circ}$ の場合に, 鋳造冠の収縮率は，それぞれ $0.16 \%, 0.17 \%, 0.28 \%, 0.32 \%$ であり，軸面傾斜度が 
大きくなるほど増加する傾向を示した．これは，外形の 寸法変化の項で述べたように，口ウ型の侧壁肉厚が大き くなるために生した結果と考えられる。このように，軸 面傾斜度が大きいほど，鋳造冠の收縮率は大きくなるに むかかわらず，適合度すなわち浮き上がり量が小さくな つた.このような結果を生じたのは，鋳造冠の浮き上が り量 (n)が，鋳造收縮と内面アラサによる 総合的な側方 方向の收縮量 ( $\mathrm{m}$ ), 拉よび支台歯の 軸面傾斜度 $(\mathrm{x})$ によつ て, $\mathrm{n}=\mathrm{m} \cot \mathrm{x}^{\circ}$ であらわされ，軸面傾斜度が大きく なつた場合に, $\mathrm{m}$ の増加率にくらべて $\cot \mathrm{x}^{\circ}$ の減少率 が大きいためと考えられる. その結果, 軸面傾斜度が $2^{\circ}$ の場合には，鋳造冠は著明な浮き上がりを示し， $5 \circ$ の 場合には $2^{\circ}$ にくらべて浮き上がり量が急激な減少を示 し， $5^{\circ}$ から $15^{\circ}$ にかけては大きな変化が認められなか つたものであり，軸面傾斜度が $2^{\circ}$ の場合には frictional fit を得るのが困難になりやすく，支台歯の軸面傾斜度 は $5^{\circ}$ 以上が好ましいといえる。一方，軸面傾斜度が同 じ場合には，歯頸部辺縁形態によつて適合度に有意差が 認められなかつた．前述の式により収縮率を求めると， たとえば軸面傾斜度が $5^{\circ}$ の場合には, knife edge type, chamfer type, および, shoulder type の鋳造冠の収縮 率は，それぞれ $0.13 \% ， 0.17 \%$ ，および $0.17 \%$ となり， knife edge type の收縮率は他の 2 者にくらべてやや小 さな值を示したが，軸面傾斜度が同じであり，鋳造冠の 浮き上がり量に有意差が認められなかつたものと考えら れる.

鋳造冠に対して，手指で強く圧迫した状態が想定され る $5 \mathrm{~kg}$ の加重を行なつた場合には，軸面傾斜度による 適合度の差がほとんど認められなくなり，咬合圧を加え た状態が想定される $30 \mathrm{~kg}$ の加重を行なつた場合には, 軸面傾斜度による影響が全く認められなくなつた.この 場合, 鋳造冠はすべて加重によつて圧入したものであ り, 鋳造冠内面と支台菌軸面の接近した距離を求めてみ ると，軸面傾斜度が $2^{\circ}, 5^{\circ}, 10^{\circ}, 15^{\circ}$ の場合に，それ ぞれ 3 5 $\mu, 3 \sim 4 \mu, 4 \sim 6 \mu, 4 \sim 8 \mu$ である. このよ うに強度の加重を行なうことにより鋳造冠が沈下するの は，加重が小さな場合には，鋳造冠内面のアレによる突 起部が支台歯と接触することにより, 鋳造冠が浮き上が りを生じていたが，加重を大きくすれば，鋳造冠内面の 突起が潰れる40)，および支台歯に圧入されるなどのため 鋳造冠が沈下したものと考えられる.そして，軸面傾斜 度が大きいほど軸面に加えられる力が大きくなるため, 鋳造冠内面と支台歯軸面の接近距離が大きくなり，軸面 傾斜度による適合度の変化が認められなくなつたと考え
られる．ちなみに，予備実験において測定した鋳造冠内 面のアラサは，最大高さ $\left(\mathrm{H}_{\max }\right) 5 \sim 10 \mu$ ，中心線平均 アラサ $\left(\mathrm{H}_{\mathrm{a}}\right)$ 1.3 1.8 $\mu$ であつた. 金パラジウム銀合 金の鋳造体のアラサに関して, 長谷川 ${ }^{30)}$ は $\mathrm{H}_{\mathrm{max}} 10 \mu$, 小貫 ${ }^{34)}$ は $\mathrm{H}_{\max } 14.8 \mu$, 総山 ${ }^{39)}$ は $\mathrm{H}_{\max } 8.7 \mu$ であつ たと報告している。本予備実験の結果は, 長谷川, 小貫 の值よりやや小さく, 総山の值とほぼ同じ值を示した が, これは，鋳造条件および金属の組成率，融点などの ちがいによるものであろう。

$400 \mathrm{~g}$ の加重を行なつた場合には，歯頸部辺縁形態に よつて適合度に差が認められなかつたにもかかわらず, $5 \mathrm{~kg}$ および $30 \mathrm{~kg}$ の加重を行なつた場合には, knife edge type の鋳造冠は, chamfer type および shoulder type にくらべて，大きな沈下を示し， ロウ型よりも沈 下寸る結果を示した. この原因としては, knife edge type の側壁下方部にお㧍る寸法変化は側壁上方部にく らべて大きいので, 支台歯の軸面が鋳造冠側壁内面の上 方部のみで接触しているためと考えられる. その結果, knife edge type の鋳造冠においては, chamfer type および shoulder type にくらべて, 接触部に加わる 圧 力が大きくなり，大きな沈下を示したものと考えられ る. また, 実験 I）の結果で示したように, 鋳造冠は長 軸方向に膨張を示し, knife edge type の鋳造冠は旃頸 部における障害がないため, 口ウ型より沈下したもので ある. なお, 本実験に使用した支台歯の硬度は, ビッカ 一ス硬度（Hv）26.5 43.2 であつた. 象牙質の硬度に 関して, 二瓶 ${ }^{41)}$ は $\mathrm{H}_{\mathrm{v}} 33 \sim 36$, 見明ら ${ }^{42)}$ は $\mathrm{H}_{\mathrm{v}} 54 \sim 60$ であつたと報告している.すなわち，本実験に使用した 支台歯の硬度は象牙質と同程度またはやや小さいことを 示し, 歯牙においても鋳造冠の加圧による適合度は同じ 傾向を示すと推定される.

以上の結果から, 鋳造冠の適合度に関して, 支台菌形 態は, 軸面傾斜度が $2^{\circ}$ の場合には frictional fit を得 るのが困難であり，5゚ 以上が望ましい，一方，歯頸部 辺縁形態は鋳造冠の適合度に大きな影響を及ぼさない。 そして, 鋳造冠に強度の加重を行なうことにより, 䤻造 冠の浮き上がりはほとんど認められなくなるけれども， 加圧によつて無理に㨂入された鋳造冠は, 試適後撤去す るのが困難になりやすく, 鋳造冠のとくに歯頸部辺縁な どをきつつけたりするため, 試適時に強度の加圧を行な うのは好ましくないと考えられる。

\section{セメント合着による浮き上がりおよび切断面のセメン ト層について}

適合のよい鋳造冠をセメント合着した場合に浮き上が 


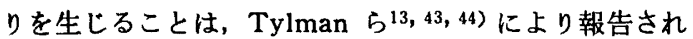
ている. そして，セメント合着による浮き上がりを防止 するために，鋳造冠に流出孔をつくる方法 $\left.{ }^{13}, 43,45\right)$, お よびrelief space を与える方法 4,6,44,46) などが報告され ている、また，セメント合着による鋳造冠の浮き上がり 量は，浮き上がり防止策を施しても，支台歯の形態によ つてその効果が異なる4,6,8)。 そこで, 支台歯形態が変化 した場合に，セメント合着による浮き上がり量はどのよ うな変化を示すのか知る必要がある.そして，セメント 合着による浮き上がりを少なくするために効率の良い支 台菌形態を知り，鋳造冠化必要な他の条件を考慮して支 台歯形熊を決め，必要があれば浮き上がり防止策を施す べきである.

鋳造冠のセメント合着による浮き上がり量は，側壁部 のセメント層の厚さに影響をうけるので，まずこの点に ついて考察してみる.

側壁部のセメント層の厚さは, 表 $6,7,8)$ および図 $21 ， 22 ， 23 ）$ に示したように, 軸面傾斜度が $2^{\circ}$ の場合 に 24 26 $\mu, 5^{\circ}$ の場合に $21 \sim 22 \mu$, および $10^{\circ}, 15^{\circ}$ の 場合に $16 \sim 18 \mu$ の值を示し, 軸面傾斜度が大きいほど 小さくなる傾向を示した.この原因として，セメントの

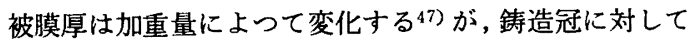
垂直に加えられる力 (1) が一定の場合に, 軸面傾斜度が $\left(\mathrm{x}^{\circ}\right)$ の支台菌の軸面に直角に働く力は $1 \sin \mathrm{x}^{\circ}$ であり， 軸面傾斜度が大きいほど軸面に働く力が大きくなるた め, セメント層の厚さが小さくなつたものと考えられ る. 次に, knife edge type の側壁セメント層は, 上方 部にくらべて，下方部で大きな值を示し，その変化は， 軸面傾斜度が小さいほど著明であつた。これは，外形の 寸法変化の項で述べたように, knife edge type の側壁 下方部の肉厚が極度に小さいために(表13), 埋没材の硬 化膨張によるロウ型の変形, および埋没材による金属の 凝固収縮の抑制などが原因と考えられる。

セメント合着による浮き上がり量は，表 5 ), 図 20) に示したように, 軸面傾斜度が $2^{\circ}$ の場合に最も大きな 值を示し, $5^{\circ}$ の場合には $2^{\circ}$ にくらべて急激な诚少を示 し, $10^{\circ}$ の場合には $5^{\circ}$ にくらべて減少したがその程度 は小さくなり, $10^{\circ}$ と $15^{\circ} に$ におてはほとんど変化が認 められなかつた. これは, 前述したように, 軸面傾斜度 が小さな場合には，側壁セメント層の厚さが大きくなる のみならず, 軸面傾斜度による綐軸方向への影響が大き いため, 相乗効果を示した結果である. 一方, 辺縁形態 の差異による浮き上がり量は, knife edge type の場合 に, chamfer type および shoulder type にくらべて,
やや大きくなる傾向を示し，この傾向は傾斜度が大きい 場合に明らかである．たとえば軸面傾斜度が $15^{\circ}$ の場合 $に$, knife edge type, chamfer type, shoulder type においてそれぞれ $53.6 \mu, 34.8 \mu, 29.2 \mu$ の浮き上が りを示したが，これらの值は，鋳造冠を $30 \mathrm{~kg}$ 加重によ り試適した状態を基準としたセメント合着による浮き上 がり量である．これらの值を，口ウ型を基準とした浮き 上がり量に換算してみると，それぞれ $36.3 \mu, 38.5 \mu$, $41.5 \mu$ となり, 辺縁形態による変化はほとんどないと おもわれる. 以上のように測定值が異なる理由は, 鋳造 冠試適時に大きな加重を行なうと, knife edge type に おいては, 無理に圧入されるのでロウ型にくらべて沈下 した状態となり，これを基準点に測定したため, セメン 卜合着を行なつた場合, 他の type にくらべて浮き上が り量が大きくなつたものと考えられる.

歯頸部辺縁のセメント層の厚さは, 表 9 ）に示したよ うに, 軸面傾斜度ならびに歯頸部辺縁形態によつて著明 な変化が認められた. 軸面傾斜度に関しては, 傾斜度が 小さいほど，セメント合着による浮き上がりが大きくな り，歯頸部辺縁のセメント層の厚さが大きくなつたもの である. 一方, 歯頸部辺縁形態に関しては, 辺縁のセメ ント層は, knife edge type の場合に最も小さな值を示 し, shoulder type の場合に最も大きく, chamfer type においてはその中間值を示した.これは, shoulder type では浮き上がり量がそのまま歯頸部辺縁のセメント層と して現われるが, chamfer type およびknife edge type では歯頸部の傾斜角度に応してその大きさが減少し， knife edge type において軸面傾斜度が小さい場合には 多少の浮き上がりがあつても，歯頸部辺縁のセメント層 に及ぼす影響が少ないためである。井手ら ${ }^{6)}$ は，このよ うな辺縁形態の特殊性について述べているが，軸面傾斜 度との関連性にはふれていない.すなわち, 表 9) に示 したように, 歯頸部辺縁のセメント屏は, 軸面傾斜度な らびに歯頸部辺縁形態の相互関係により決をり, knife edge type $の 5^{\circ}$, chamfer type $の 10^{\circ}$, および shoulder type の $15^{\circ} に$ におてほほ同じ值を示した.このよ うな軸面傾斜度ならびに歯頸部辺緣形態の関連性を考虑 して，支台歯形態を決めるべきである.

セメント合着による浮き上がりを小さくするために種 々の方法が報告されている4,6,13,15,44,47). しかし, 支台 歯の軸面傾斜度が小さな場合には, 実験結果で示したよ うに，セメント合着による浮き上がり量が大きく，浮き 上がりを防止するためには大きな relief space が必要 であり4), relief space を大きくすれば, 鋳造冠に種々 
の欠点を生ずるおそれがある，たとえば，模型にマニキ ユアや石育などを盛り上げてロウ型採得を行なう方法で は，軸面傾斜度が小さな場合，軸面にアンダーカットを 生じる危険があり，また， 口ウ型の側壁肉厚がいつそう 薄くなるので変形を起こしやすい欠点がある.

以上のように，軸面傾斜度が小さな場合には，セメン 卜合着による浮き上がり量が大きく，煩雑な浮き上がり 防止策を行なつてもその効果が少ない，あるいは鋳造冠 に欠点を生じるため好をしくない，そして，セメント合 着による浮き上がり量を少なくするためには， $5^{\circ}$ 以上 の軸面傾斜度が望ましいと考えられる．また，歯頸部辺 縁のセメント層を小さくするために, shoulder type の 軸面傾斜度は10 1 $15^{\circ}$ にする必要がある. しかし, shoulder type の鋳造冠は側壁の肉厚が大きいため, 浮き上 がり防止方法を行なつても鋳造冠に欠点を生じる危険が 少ないので, 軸面傾斜度を $5 \sim 10^{\circ}$ にして, 浮き上がり 防止策を併用し，セメント合着による浮き上がりおよび 歯頸部辺縁のセメント層を小さくする方法も考えられ る.

\section{保持カについて}

歯冠修復物の保持力に影響を及ぼす因子としては, 形 成された歯牙に扔ける因子 7,8,9,48,49), 鋳造体における因 子50,51)，および合着材としてのセメントにおける因子が

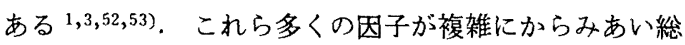
合的に保持力が決まるのみならず，修復物を装着した人 の咀嚼習慣および咬合力などが異なるので, 臨床的に必 要な保持力を究明するのが困難である.しかし，歯冠修 復物のなかでは鋳造冠が最も大きな保持力をもつている と考えられており，その引張り強さを比較した研究報 告59)においても，ピンレッジや $3 / 4$ 冠などの一部被覆 冠にくらべ，鋳造冠の引張り強さがもつとも大きかつた と報告されている。一方，尾花 ${ }^{54)}$ は，ピンレッジの保 持力について検討し統計的な臨床観察を行なつた結果ピ ンレッジは橋義歯の支台装置としても十分な保持力をも つていると考えられる，と述べている。これらの報告か ら推定すれば，鋳造冠は必要以上に大きな保持力をもつ ているかもしれない，しかし，臨床において，鋳造冠の 支台歯形成を行なう場合には，軸面傾斜度を大きくすれ ば鋳造冠の保持力が低下することを恐れ，軸面傾斜度を

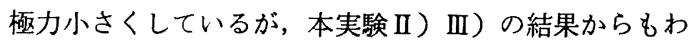
かるように，鋳造冠の適合度あるいはセメント合着によ る浮き上りなどへの影響について充分な配慮が必要であ ると考えられる.

本実験においては，支台歯と鋳造冠が離脱するに要し
た力を測定し，鋳造冠の保持力について検討したもので ある、この場合，支台歯形態による保持力は，表10,11） に示したように, 単位面積当りの引張り強さについて比 較せずに, 1 歯単位の引張り強さを比較した. これは, 鋳造冠の保持力を比較する場合に，対象となる菌牙の歯 頸部の大きさおよび高さは一定であり，支台歯形成を行 なうことによつて支台蒾形態が異なれば，当然支台歯の 表面積も変化するものであり，支台歯形態による鋳造冠 の保持力を比較する場合には，1歯単位の保持力を比較 するのが妥当であると考えたためである.

軸面傾斜度による鋳造冠の引張り強さは, 表10）に示 したように, $2^{\circ}, 5^{\circ}, 10^{\circ}, 15^{\circ}$ の場合にそれぞれ $79.2 \mathrm{~kg}$, $34.0 \mathrm{~kg}, 22.8 \mathrm{~kg}, 15.1 \mathrm{~kg}$ の值を示し, 軸面傾斜度が 大きくなるほど, 漸次減少した. 鋳造冠の引張り強さ (y) と, 軸面傾斜度 $(\mathrm{x})$ の関係について調べてみると, 両 者は直線的な関係を示していない.そこで両者の関倸を $\mathrm{y}=\mathrm{ax}^{\mathrm{b}}$ と仮定し，対数方眼紙に plot してみると直線的 な関係を示すので, $\mathrm{x}$ と $\mathrm{y}$ の関係は

$$
\log y=A \log x+B
$$

である. 各 plot から最小自乗法によつて A, B を求め ると

$$
\mathrm{A}=-0.80, \mathrm{~B}=2.13
$$

となり, 引張り強さと軸面傾斜度の関係は

$$
\mathrm{y}=134 \mathrm{x}^{-0.80}
$$

であらわされる.

一方, 歯頸部辺縁形態が変化した時における鋳造冠の 引張り強さは, 表11）に示したように, いずれも20〜22 $\mathrm{kg}$ の值を示し, 有意差が認められなかつた. これらの ことについて考察してみる.

鋳造冠の保持力に影響を及ぼす因子に関して, 本実験 においては，セメントの種類および練和条件が一定であ るのでセメントの破砕抗力は変化しない. また, 接着面 のアラサは, 支台歯では $\mathrm{H}_{\max } 2 \sim 3 \mu, \mathrm{H}_{\mathrm{a}} 0.3 \sim 0.5 \mu$ の值を示し, 鋳造冠内面では $\mathrm{H}_{\max } 5 \sim 10 \mu, \mathrm{H}_{\mathrm{a}} 1.3 \sim$ $1.8 \mu$ の值を示し, 保持力への影響はほとんどないと考 えられる. そして, セメント層の厚さに関しては, 実験 IV) の結果に示したように, 支台歯形態によつて変化が 認められた. セメント層の厚さと保持力に関して, 岩 本 ${ }^{55)}$ は, セメント層の厚さが約 $35 \mu$ の場合に最大の合 着力を示したと報告している. また, J J rgensen ${ }^{53)}$ は, セメント層の厚さが $20 \sim 140 \mu$ に変化した場合に, 鋳 造冠の保持力は, $20 \mu$ において最大であり, セメント 層が大きいほど減少したが有意差は認められず，セメン

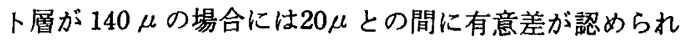


たと報告している．本実験における側壁セメント層の変

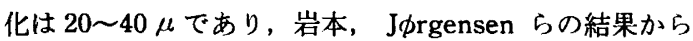
考察すれば，側壁セメント層の厚さの変化が鋳造冠の保 持力に及ぼす影響はきわめて少ないと考えられる.とこ ろで，鋳造冠の保持力はセメント合着によつて生じるも のであるが，セメントには接着性がほとんどないといわ れており ${ }^{56)}$, 合着力はセメントの嵌合効力によつて生じ ると考えられている ${ }^{57)}$. 嵌合勃力は, 支台歯および鋳造 冠の表面の凹凸にセメントが嵌入し, 離脱力に抵抗する ことによつて生じるものであり，支台歯と鋳造冠が離脱 するのは, アンダーカットに存在するセメントが破壊す るためである.そして，離脱させようとする力の方向と 接着面の角度が大きくなれば，アンダーカットが少なく なるため嵌合効力が小さくなる.

すなわち，支台歯の軸面傾斜度が大きくなれば，離脱 力の方向に対する接触面の角度が大きくなるため, 鋳造 冠の保持力が低下したものであり, 歯頸部辺縁形態が異 なつた場合でも軸面傾斜度が同じであるため保持力に変 化が認められなかつたものと考えられる.

鋳造冠の保持力に関して，臨床において鋳造冠がいか なる大きさの引張り強さを持つていれば, 脱落を起こさ ずに十分使用に耐え得るかという問題は解決されていな い.しかし，鋳造冠と対比する意味でピンレッジの引張 り強さを測定した結果, ピンレッジの引張り強さは, 軸 面傾斜度が $15^{\circ}$ の鋳造冠のそれよりやや大きな值をした が，両者に有意差を認めなかつた。このことに関して， Lorey ${ }^{50)}$ は, 鋳造冠の保持力がピンレッジの 約 2 倍の 值を示したと報告しており，これは本実験における軸面 傾斜度が $5^{\circ}$ の釷造冠とほぼ一致する.

以上のような結果から推定すれば，軸面傾斜度が $10^{\circ}$ 以下の鋳造冠は臨床的に必要かつ十分な保持力をもつて いると推定できる.

以上，各項目について考察を行なつてきたが，支台歯 の軸面傾斜度ならびに歯頸部辺縁形態が鋳造冠に及ぼす 影響について，さらに総合的検討を加えることにする.

軸面傾斜度が小さい場合，すなわち $2 \sim 5^{\circ}$ では，鋳造 冠は, 保持力が大きく, 外形寸法とくに接触点部の収縮 が少ないなどの利点がある．また，歯質の削除量が少な いので, 歯髄への為害作用が少ないと考えられる ${ }^{58}$. し かし, 適合度に関しては, frictional fit を得るのが困難 であり，セメント合着による浮き上がりが大きくなり， 辺縁形態が chamfer type, shoulder type の場合には 菊頸部边縁のセメント層が 非常に大きくなり, knife edge type の場合には側壁肉厚が非常に小さくなるた
め，側壁部が変形を起こしやすいなどの欠点がある．ま た，臨床に㧍いては，支台歯形成に高度の技術を要し， 時として部分的なアンダーカットを生じやすく，架工義 歯の支台装置として使用する場合には平行性を欠くこと がある、また，セメント合着による浮き上がりを防止す るために relief space を付与する場合には，大きな relief space が必要であり, 鋳造冠の保持力の低下を招 いたり, 辺縁形熊が knife edge type の場合には, 側 壁部の変形を起こしやすい.

軸面傾斜度が $5 \sim 10^{\circ}$ の場合には, 鋳造冠の適合度は frictional fit を呈しやすく, セメント合着による浮き 上がり量は比較的小さいので，浮き上がり防止策を施す ことなく, 臨床的には研磨, 咬合調整などによつて解決 できる程度であり, 保持力は臨床的に必要かつ十分であ ると考えられる。また，歯頸部辺縁のセメント層は， knife edge type および chamfer type の場合には小さ くなるが, shoulder type の場合にはやや大きくなるの で好ましくない，そこで， shoulder typeの場合には浮 き上がり防止策を施す必要がある。しかし，この場合に は, relief space が小さくても効果があると考えられ, かつ側壁肉厚が大きいので，軸面傾斜度が小さな場合に 生じる危険性はほとんどないと考えられる。また, knife edge type の場合には, 比較的側壁下方部の肉厚が小さ く, 側壁下方部はわずかに変形を起こすので, 臨床にお いては，口ウ型採得時に側壁下方部の肉厚が小さな部分 に余分の口ウを盛り上げて，鋳造冠完成後に外形形態を 修正する方法を行なうのが望をしいと考えられる.

軸面傾斜度が大きな場合，すなわち $10^{\circ}$ 以上では，鋳 造冠の適合度はf frictional fit を呈しやすく,セメント合 着による浮き上がりが少なく，かつ歯頸部辺縁のセメン 卜層が小さくなるなどの利点がある. しかし，保持力が 不足する危険率が高くなり，外形寸法とくに接触点部の 収縮が大きいなどの欠点がある，また，歯質の削除量が 多いので, 症例によつては露髄を起こし, 歯髄への為害 作用が大きくなると考えられるため，好ましくない，

これらのことから，鋳造冠の外形寸法，適合度，セメ ント合着による浮き上がり, 歯頸部辺縁のセメント層, および保持力について, 補緅学的な立場から総合的に判 断すると, 鋳造冠の支台歯形態は, 軸面傾斜度を $5 \sim 10^{\circ}$, 歯頸部辺縁形態を knife edge type にする方が良いこ とがわかる.そして，歯頸部辺縁形態を chamfer type あるいは shoulder type にせざるを得ない場合には, knife edge type の場合よりも軸面傾斜度を大きくする 方が良いことがわかる. 


\section{結論}

支台歯の軸面傾斜度ならびに歯頸部辺縁形態が，鋳造 冠の外形寸法, 適合度, セメント合着による浮き上が り，歯頸部辺縁のセメント層，および保持力に及ぼす影 製について知ることを目的として実験し，次の結果を得 た.

1. 鋳造冠の外形寸法は, 冠縦軸方向に膨張し, 横方 向に収縮した。この場合，縦軸方向の膨張は支台歯形態 による変化が認められなかつた. 一方, 横軸方向の収縮 は, knife edge type において, chamfer type および shoulder type にくらべて少ない傾向を示し, 軸面傾斜 度が大きいほど大きくなる傾向を示した.

2. 鋳造冠の適合度は, 加重量が小さな場合には, 軸 面傾斜度が $2^{\circ}$ の場合に最も大きな浮き上がりを示し， $5^{\circ}$ の場合には $2^{\circ}$ にくらべて急激な浮き上がり量の減少 を示したが， $5^{\circ}$ から $15^{\circ}$ にかけては大きな変化が認め られなかった.この場合, 歯頸部辺縁形態による浮き上 がり量の変化はほとんど認められなかつた.

3. 七メント合着による浮き上がり量は, 軸面傾斜度 が $2^{\circ}$ の場合に最も大きな值を示し， $2^{\circ}$ から $5^{\circ}$ にかけ て急激な減少を示し, $5^{\circ}$ から $10^{\circ}$ にかけては減少する 程度が小さくなり，10から $15^{\circ}$ にかけてはほとんど変 化が認められなかつた。

4. 歯頸部辺縁のセメント層は, knife edge type で 最も小さな值を示し, chamfer type, shoulder type の 順に大きな值を示した．また，軸面傾斜度が大きいほど 辺縁のセメント層は小さくなる傾向を示し, その変化は shoulder type の場合に最も著明であつた。なお, knife edge type の $5^{\circ}$ に㧍ける歯頸部辺縁のセメント層の厚 さは, chamfer type の $10^{\circ}$, および shoulder type の $15^{\circ}$ におけるそれとほぼ同じ值を示した.

5. 鋳造冠の引張り強さは, 軸面傾斜度が $2^{\circ}$ の場合 に最も大きな値を示し，軸面傾斜度がが大きくなるほど 漸次減少した. また，歯頸部辺縁形態による鋳造冠の引 張り強さは変化が認められなかつた. 鋳造冠の引張り強 さと軸面傾斜度との関係は $\mathrm{y}=134 \mathrm{x}^{-0.80}$ であつた。

以上の結果，鋳造冠に扮ける適合度を良くし，セメン 卜合着による浮き上がりおよび歯頸部辺縁のセメント層 を小さくし，かつ保持力を増すためには，軸面傾斜度を 5〜10にする方がよい，また，歯頸部辺縁のセメント 層を小さくするためには, 歯頸部辺縁形態を, chamfer type および shoulder type よりも, knife edge type
にする方がよい.なお， chamfer type あるいは shoulder type にせざるを得ない場合には，歯頸部辺縁のセ メント層を小さくするために, knife edge type の場合 よりも軸面傾斜度を大きくする方がよいことがわかつ た.

稿を終るに臨み、ご指導、ご校閱をいただいた大阪大学歯 科補緅学第一教室下総高次教授に深愔いたします。またこご 校閲をいただいた本学理工学教室井田一夫助教授に謝意を表 し，いろいろと協力して下さつた当教室員諸兄に厚くお礼申 し上げます，最後に，実験器具についてご協力いただいた， 松風陶歯製造株式会社研究部の林昭三氏に対しても併せて感 謝申し上げます.

本論文の要旨は昭和45年10月15日，第57回日本補緅歯科学 会において発表した.

\section{文献}

1) Kaufman, E.G., Colin, L., Schlagel, E. and Coelho, D.H. : Factors influencing the retention of cemented gold castings: The cementing medium, J. Pros. Dent., 16 : 731-739, 1966.

2) J $\phi$ rgensen, K.D. : The relationship between the retention of cemented venner crowns and crushing strength of the cements, Acta Odont. Scand., 25 : 355-359, 1967.

3）総山孝雄：精密鉡造に関寸る研究，歯材器誌，7：3655 , 昭和37 (1962).

4）吉田恵夫, 佐藤弘, 鹿沼晶夫, 田端恒雄：セメント合着

-による鏻造冠の浮き上りについて：第一報 金属原型使 用の場合, 補緅誌, $4: 157-161$, 昭和35 (1960).

5) J $\phi$ rgensen, K.D. : Factors affecting the film thickness of zinc phosphate cements, Acta Odont. Scand., $18: 479-490,1960$.

6）井手喜美子、総山孝雄：セメント合着による 全部鋳造 冠の浮き上りを防止する一法について，日保存誌，4： 118-126, 昭和36 (1961).

7) J $\phi$ rgensen, K.D. : The relationship between retention and convergence angle in cemented veneer crowns, Acta Odont. Scand., $13: 35-40,1955$.

8) Kaufman, E.G., Coelho, D. H. and Colin, L. : Factors influencing the retention of cemented gold castings, J. Pros. Dent., $11: 487-502,1961$.

9）大橋康良：架工義歯の前歯支台装置に関する研究：第 1 編 歯面傾斜度と Cement 合着力との関係，歯科学報， $68: 715-725$, 昭和 43 (1968).

10）角田篤美，橋本収，宗本匡由，荒木啓之：蔽冠之歯肉の 
形態に関する統計的観察，阪大歯学誌，13：371-379, 昭和43 (1968).

11）中村健吾：歯科における $\mathrm{QC}, \mathrm{DE}, 4: 1-3$, 昭和 43 (1968).

12）畑好昭：印象採得から鋳造までの諸因子が鈜造冠の精度 におよぼす影響について，歯学，56：748-771，昭和 44 (1969),

13) Tylman, S.D. : Theory and practice of crown and fixed partial prosthodontics, St. Louis, 1970, The C.V. Mosby Co.

14) Ewing, J.E. : Fixed partial prosthesis, Philadelphia, 1954, Lea \& Febiger.

15）石原寿郎：䤿造冠, 東京, 昭和 34 , 而至化学工業株式会 社.

16）多和田泰一：鋳造冠支台形成の要点, 画界展望, $26: 11-$ 20 , 昭和 40 (1965).

17）中沢靖, 渡辺真宏：タービン時代の支台歯形成, 歯界展 望, $30: 394-400$, 昭和 42 (1967).

18）小森富夫, 鉒谷博之：全部錆造冠, G-C 臨床シリーズ, $33: 9-23$, 昭和 45 (1970),

19）黑江良治, 八幡昌介, 長谷川潤, 营沼聡介, 四条進 : 支 台苗辺縁部の形態の差異に依る 全部鏻造冠の寸法精度， 歯学, $55: 64$, 昭和 42 (1967).

20) Koivumaa, K.K. and Wennstrom, A. : A histological investigation of the changes in gingival margins to gold crowns, Odontologisk Tidskrift, $68: 373$ $-385,1960$.

21) McDonagh, A.J. : Periodontology with specal reference to recession of the gums, J.D. Res., 1:423439, 1919. p. 187-201.

22）秋吉正豊：歯周組織の咬合性外傷：歯科口腔外科最近の

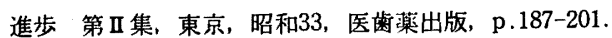

23) Stahl, S.S. : Response of the periodotium, pulp and salivary glands to gingival and tooth injurynin young adult male rats, I. Periodontal tissues, Oral Surg., $13: 613-626,1960$.

24) Thoma, K.H. : Oral Pathology, St. Louis, 1954, The C.V. Mosby, Co.

25) Beust, T. : Con.act point caries, J.D. Res., $15: 453$ $-455,1936$.

26）河野篤, 細田裕康 : 石綿带裏装の厚さと鋳造体の膨縮変 化との関係について, 歯材器誌， $12: 31-34$, 昭和 40 (1965),

27）山根正次，若松良徳：歯科錆造体の精度に関する研究： 第一報 アスベスト裹装の影響について，理工誌， 7 : 16-21, 绍和41 (1966).

28) Symd, E.S. : Factors which influence casting accuracy; A universal casting technic, J. A.D. A., 36 :
160-172, 1948.

29) Phillips, R.W., Swartz, M.L., Norman, R.D. : Materials for the practicing dentist, St. Louis, 1969, The C.V. Mosby, Co., : 川原春幸 : 臨床家のための歯 科材料学, 東京, 昭和 46 , 医蒾薬出版.

30）長谷川二郎：インレーの鋳造精度に関する実験的研究, 歯科学報, $63: 415-440$, 昭和38 (1963).

31）上新和彦, 溒淳三：リン酸塩を結合材とした埋没材の諸 性質とその適合性について，理工誌，11:124-133，昭 和45 (1970).

32）真坂信夫，金竹哲也：埋没材の強さが錆造精度に及ぼす 影響について，歯科学報，68：1126-1127,昭和43 (1968).

33）下総高次：研磨の理論と実際, 東京, 昭和33, 医歯蒋出 版.

34）小資伸一：歯科補綴物の仕上加工に関寸る研究，補緅誌， $12: 215-239$, 昭和43 (1968).

35) Brenner, E.O. : Contact point guage,; As applied to cast restoration, D. Digest, $65: 113-117,1959$.

36）渡辺富士夫：隣接面窝洞における接触回復の意義とその 要点, 菌界展望, $16: 703-707$, 昭和34 (1959).

37）井上昌幸, 草刘立, 鈴木康夫 : 接触点の回復 その考え 方と方法, 歯界展望, $35: 1517-1525$, 昭和35 (1970).

38）吉田恵夫：歯科鋳造法の実用的精度について, 補緅誌, $2: 159-190$, 昭和33 (1958)

39）総山孝雄, 井手喜美子：各種インレー用合金の鋳造収縮 に関寸る実験, 歯材器誌, 4:111-116, 昭和34 (1959).

40) Fusayama, T. : Factors and technique of precision casting, Part II, J. Pros. Dent., 9:486-497, 1959.

41）二瓶一郎：入歯牙硬度に関する研究, I, II, 阪大歯学誌 $4: 1-20,177-181$, 昭和34 (1959).

42）見明清：人の歯牙硬組織の微小硬度に関する研究，第二 報，歯科学報， $67: 65-90$ ，昭和42（1967）.

43) Jones, R.R. : A full gold crown, cast and readapted, J.A.D.A., $34: 605-606,1947$.

44) Rudolph, J. : The cast gold crown, D. Digest, 51 : 68-71, 1945.

45) Selberg, A. : A full cast crown technique, J. Pros. Dent., $7: 102-122,1957$.

46）細野来馬：間接法におうる歯冠補緅(1)，(2)，(3)，(4)歯界 展望，15：220-228，329-337，1016-1024，1339-1349， 昭和33 (1958).

47) Sullivan, E.J. : Cementation and esthetic problems in crown and bridge procedures, J.A.D.A., $51: 34$ $-47,1955$.

48) Charbeneau, G.T., Peyton, F.A. and Anthony, D. H. : Profile characteristics of cut tooth surfaces, developed by rotating instrument, J. Dent. Res., 36 : 957-966, 1957. 
49) Smith, B.G.N. : The effect of the surface roughness of preparated dentine on the retention of castings, J. Pros. Dent., 23 : 187-198, 1970.

50) Lorey, R.E., Meyers, G.E. : The retentive qualities of bridge retainers, J.A.D.A., $76: 568-572,1968$.

51) Berkson, R. : Dental cement; A study of its property of adhesion, Am. J. Orthodont., 36:701-710, 1950.

52) Richter, W.A., Mitchem, J.C. and Brown, J. D. : Predictability of retentive values of dental cements, J. Pros. Dent., 24 : 298-303, 1970.

53) J $\phi$ rgensen, K.D. : The relationship between the film thickness of zinc phosphate cement and the retention of veneer crowns, Acta Odont. Scand., $26: 169$
$-175,1968$.

54）尾花甚一：ピンレッヂによる橋義歯補緅の子後に関する 臨床的観察, 補緅誌, $2: 229-234$, 昭和33 (1958).

55）岩本次男：燐酸亜鉛セメントの被膜厚と合着力. 歯材器 誌. $4: 98-106$, 昭和34 (1959).

56) Swarz, M.L., Phillips, R. W., Day, R. and Johnston, J.F. : A laboratory and clinical investigation of certain resin restorative and cementing materials, I, II, J. Pros. Dent., 5 : 698-704, 705-710, 1955.

57) Skinner, E.W. and Phillips, R.W. : The science of dental materials, Philadelphia, \& London, 1960, W.B. Sanders Co..

58) Peeso, : The A.B.C. of crown and bridge work, Dental Cosmos, $45: 95-100,1903$. 